\title{
CEsifo WORKING

\section{How Do School District Boundary Changes and New School Proposals Affect Housing Prices}

Xiaozhou Ding, Christopher Bollinger, Michael Clark, William Hoyt 


\section{Impressum:}

CESifo Working Papers

ISSN 2364-1428 (electronic version)

Publisher and distributor: Munich Society for the Promotion of Economic Research - CESifo

$\mathrm{GmbH}$

The international platform of Ludwigs-Maximilians University's Center for Economic Studies and the ifo Institute

Poschingerstr. 5, 81679 Munich, Germany

Telephone +49 (0)89 2180-2740, Telefax +49 (0)89 2180-17845, email office@cesifo.de

Editor: Clemens Fuest

www.cesifo-group.org/wp

An electronic version of the paper may be downloaded

- from the SSRN website: www.SSRN.com

- from the RePEc website: www.RePEc.org

- from the CESifo website: www.CESifo-group.org/wp 


\title{
How Do School District Boundary Changes and New School Proposals Affect Housing Prices
}

\begin{abstract}
In the past fifty years, a voluminous literature estimating the value of schools through capitalization in home prices has emerged. Prior research has identified capitalized value using various approaches including discontinuities caused by boundaries. We use changes in school boundaries and the proposal of a new school. Our findings from redistricting in the Fayette county school district (KY) show that prices for homes redistricted from a lower-performing (based on test scores) school into the proposed school catchment area increase by six percent. For houses in higher-performing school catchment areas redistricted to the proposed new school district, there is a smaller increase in value. Houses redistricted from higher-performing schools to lower-performing schools decrease in value by three to five percent. However, many of the redistricted properties see little or no significant change, suggesting that only extreme changes in school quality are capitalized. We estimate that homes in the redistricted areas increased by \$108 million relative to homes that were not redistricted.
\end{abstract}

JEL-Codes: D100, I200, R300.

Keywords: property values, hedonics, school quality, school district, difference-in-differences.

$$
\begin{gathered}
\text { Xiaozhou Ding* } \\
\text { Department of Economics } \\
\text { University of Kentucky } \\
\text { USA - Lexington, KY 40506 } \\
\text { xiaozhou.ding@uky.edu }
\end{gathered}
$$

Michael Clark

Center for Business and Economic Research

University of Kentucky

USA - Lexington, KY 40506

michael.clark@uky.edu

\author{
Christopher Bollinger \\ Department of Economics \\ University of Kentucky \\ USA - Lexington, KY 40506 \\ crboll@email.uky.edu
}

William Hoyt
Department of Economics
University of Kentucky
USA - Lexington, KY 40506
whoyt@uky.edu

William Hoyt

Department of Economics

whoyt@uky.edu

*corresponding author

We are grateful to Samuel Ingram, Lala Ma, Rudolf Marty, Alexander McGlothlin, Anthony Yezer, and conference and seminar participants at the North American Regional Science Council Annual Meetings, Labor (Applied Micro) Group Meeting at University of Kentucky, and Kentucky Economic Association Annual Conference for helpful comments and discussions. We also thank David O’Neill, Fayette County PVA, and Lexington-Bluegrass Association of Realtors for their help on this project. 


\section{Introduction}

There were 89,528 public elementary and secondary schools operating in the United States during the 2014-2015 school year. Among those schools, 126 changed agency or boundary and 390 were expected to open within 2 years ${ }^{1}$. The opening and closure of schools not only affects students and parents, but also the home values in the school district (catchment area for individual schools) as many households purchase a home to gain access to better schools for their children. A survey of recent home buyers found that fifty-three percent of households with children under the age of eighteen said that the quality of the school district as important in their housing decisions and fifty percent cited convenience to schools as important. ${ }^{2}$ According to a local news report, redistricting Henrico County, Virginia in 2017 drew criticism from some elementary school parents in the county, "[s]ome parents explained that they moved into a house thinking their kid would go to a certain middle school". ${ }^{3}$ This underscores the importance in understanding how people make housing choices and how they value a change in attendance boundaries.

In contrast to the traditional approach of identifying the impacts of schools and school quality on property values through cross-sectional variation in quality among schools or through boundaryfixed effects (Black, 1999), we take advantage of recent high school redistricting in Fayette County, Kentucky using a difference-in-differences approach. Our identification of the value of schools is unique: we are able to measure how housing prices change when a neighborhood is redistricted from one school to another. We are also able to identify how adding a new school to the system changes prices for houses redistricted to the new school. Because during the period of our sample the new school is only proposed and not yet open, we are capturing the expected valuation of a future school. As we discuss in Section 2, we believe using the difference-in-differences approach provides distinct advantages over earlier approaches. Further, as we have comprehensive data on (mean) ACT scores for the public high schools in Fayette County, we also contribute to the voluminous literature on the capitalization of school quality measures.

The Lexington-Fayette Board of Education approved a new boundary plan on June 3, 2015 for

\footnotetext{
${ }^{1}$ U.S. Department of Education, National Center for Education Statistics, Common Core of Data (CCD), "Public Elementary/ Secondary School Universe Survey", 2014-15, Provisional Version 1a and "Local Education Agency Universe Survey" 2014-15, Version 1a.

${ }^{2}$ National Association of Realtors, “2018 Profile of Home Buyers and Sellers," https://www.nar.realtor/sites/default/files/documents/2018\%20HBS\%20Highlights.pdf

${ }^{3}$ http://wtvr.com/2017/06/22/henrico-school-board-votes-for-option-e-middle-school-redistricting-plan/
} 
the five high school catchment areas in Fayette County. ${ }^{4}$ At this time, a new high school, Frederick Douglass, was also proposed (opened in August 2017). The catchment zone for Douglass is between those of the Bryan Station High School and Henry Clay High School catchment zones prior to its opening in Fall 2017 (see Figure 1b). These changes in boundaries are the basis of the natural experiment we exploit to examine the effects of school quality on housing prices.

We implement a difference-in-differences (DD) approach to investigate the multiple and distinct effects of redistricting on house values in different school catchment areas. Implementing the DD approach using boundary changes for several high schools in Fayette county allows us to investigate the impacts of boundary changes on property values in the different catchment areas - essentially allowing for less parameterized estimation. Our results show that redistricting proposed in 2015 increases housing values by 2.4 percent on average for those houses redistricted to another high school. When examining changes in property values by pairs of schools we find that only houses redistricted from the lowest-performing school (Bryan Station) to other existing schools gained value significantly. However, houses redistricted from existing high schools to the proposed school all had significant increases in value. Moreover, for most of the current higher-performing schools, values of redistricted houses did not suffer a significant negative impact due to the redistricting. Our analysis also implies that test score changes contribute to changes in housing values - a one point increases in ACT score increases (mean) housing values by 0.6 percent after the boundary change.

We use our findings in conjunction with a simple open-city model developed in Section 3 to provide some insights on the impacts of redistricting on aggregate welfare subject to several important caveats. Based on our estimation of the effects of the proposed new school we estimate that aggregate property in Fayette county increases by 108 million dollars.

In Section 2 we provide a brief review of the literature on the relationship between education and property values. As mentioned, Section 3 presents a simple open city model to motivate our examination of how these boundary changes and the opening of a new school affect aggregate benefits in the city. Background on the process for determining school boundaries is discussed in Section 4 while Section 5 provides the basic methodology and discusses the data used in empirical

\footnotetext{
${ }^{4}$ The five operating high schools in Fayette County prior to August 2017 are Bryan Station, Paul L Dunbar, Henry Clay Lafayette, and Tates Creek as can be seen in Figure 1a
} 
analysis. Section 6 presents the results of estimation and Section 7 provides an extensions that addresses the possibility of learning in the model and provides a placebo test. Section 8 concludes.

\section{Literature Review}

Economists have long been interested in estimating the relationship between housing prices and school quality. Early work done by Oates (1969) and Kain and Quigley (1970) inspired a burgeoning literature examining the impact of school quality on property values. A critical problem associated with evaluating the casual link between housing price and school quality is controlling for neighborhood characteristics. As "good" schools are often correlated with other neighborhood amenities, it is difficult to isolate the effect of school quality from the effects of these amenities through ordinary least squares regressions. If increased housing prices increase property tax revenues, a greater willingness to pay for school quality in a district will lead to increased school spending making school quality endogenous to the district (Nechyba, 2003; Epple and Romano, 2003). Bogart and Cromwell (1997) use an Oaxaca-decomposition to examine houses across school districts where jurisdiction districts are overlapped and isolate the common public service effect from observable component and unobservable component. Weimer and Wolkoff (2001) also follow the same spirit finding significant impact of test scores on housing values.

Black (1999) is the first paper to apply boundary fixed effect to the estimation of hedonic models. She uses elementary school data in Massachusetts and compares houses within similar neighborhoods but across school attendance boundaries. The cross-sectional regression results show 2.5 percent increase of house prices for a five percent increase in test scores. Gibbons, Machin, and Silva (2013) use British data and boundary discontinuities to examine the response of housing prices to school-mean test scores and also initial characteristics of students and find equal effects.

Various papers also implement different methods together to examine the relationship between school quality and property values. Downes and Zabel (2002) adopt a standard log-linear regression, a first-difference model, and a value-added model to examine the impact of school characteristics on housing prices. They find that individuals are willing to pay more for a house close to a school with higher standardized test scores. ${ }^{5}$ Gibbons and Machin (2003) use semi-parametric

\footnotetext{
${ }^{5}$ They point out that district-level measures of school attributes will create biases in the estimated effects of school characteristics comparing to school-level measures.
} 
regression, discontinuities at school boundaries, as well as instrumental variable approach. In Gibbons and Machin (2006), they look into the relationship between school popularity and housing prices using instrumental variable and boundary fixed effect. Because of institutional factors in the United Kingdom, distance to schools plays an important role in determining school choice. They find a one standard deviation increase in school quality increase sales prices by 3.8 percent but this premium differs with distance to school. Clapp, Nanda, and Ross (2008) use a panel of school districts in Connecticut to examine the effect of school district test scores and demographic composition on housing prices after controlling for the influence of unobserved neighborhood attributes with fixed effects. They find a one standard deviation increase in test scores leads to 1.3 percent increase in property values. They also find that a 10 percentage point increase in the percent of African-Americans and Hispanic leads to a 3.5 percent and 3 percent decline in property values respectively, a result that is not consistent with their earlier work that finds no effect of math scores on housing prices and demographic changes do not affect across-town differences (Clapp and Ross, 2004). Cellini, Ferreira, and Rothstein (2010) utilize discontinuities in voting on education spending to see the impact of school facility investment on housing markets and find $\$ 1$ increase in spending increase housing prices by $\$ 1.5$ and effect from test scores is small.

While the boundary fixed effect approach has distinct advantages, recent studies have identified several concerns with this approach. One issue that affects the interpretation of the estimates is that with growing school districts, school boundaries are uncertain and subject to change. In this case, risk reduces the extent of capitalization (Cheshire and Sheppard, 2004). In contrast, while the boundary fixed effect literature is based on the assumption that houses near school boundaries are in the "same" neighborhood and exhibit the same characteristics, along long-lasting boundaries sorting based on school quality is likely to occur. Bayer, Ferreira, and McMillan (2007) provides strong evidence for clear differences in demographics (parents' college education, percentage black, income) along school catchment boundaries in the San Francisco MSA. Using boundary fixed effects with neighborhood demographic controls, Bayer, Ferreira, and McMillan (2007) find that the impact of school quality on property values is reduced by almost fifty percent relative to estimates with the boundary fixed effects alone. Kane, Riegg, and Staiger (2006) use boundary fixed effect and regression discontinuity methods with data from Mecklenburg County, North Carolina between 1994 and 2001 to study the impact of various school characteristics on housing prices. 
They test whether observed housing and neighborhood characteristics shift discontinuously at the school boundaries and find pronounced correlation between differences in school test scores and differences in housing and neighborhood characteristics, which shows the importance to control for these differences. An alternative approach to addressing these concerns with boundary fixed effects is to control for demographic differences that may arise from sorting and employ panel data (repeated cross-sections) along boundaries (Dhar and Ross, 2012; Dachis, Duranton, and Turner, 2012).

In addition to the widely-used boundary fixed effect model pioneered by Black (1999) and its modifications discussed above, the literature has also been moving to using quasi-experimental approaches. A number of studies adopt exogenous changes to identify the effect of school quality on housing prices. Bogart and Cromwell (2000) employ a difference-in-difference framework to examine the impact of redistricting schools on house values in Shaker Heights, Ohio where school closing in 1984 and 1987 resulted in dramatic shifts in boundaries. They find the impact of losing a neighborhood school on home values reduces house values by 9.9 percent $(\$ 5,738$ at the mean house value). However, as all schools in Shaker Heights are considered to be of high quality, they are not able to exploit variations in quality of schools. Ries and Somerville (2010) use repeated sales in Vancouver and exploit a redistricting process that redraws catchment areas to study the impact of school quality on housing values. They find the only significant effects of this redistricting occur for top-quartile residences. Machin and Salvanes (2016) use Norwegian data to examine whether access to school choice affect housing prices. They utilize the policy change of removing catchment areas and find housing valuation sensitivity is reduced, which proves parents value better performing schools. Bonilla-Mejía, Lopez, and Mcmillen (2018) take the reform of school lottery in Chicago to study the capitalization effect and find significant impact of higher admission probability associated with close proximity on housing prices. Collins and Kaplan (2017) utilize exogenous boundary changes in Shelby County, Tennessee to estimate the effects of school quality and district attributes on housing prices. They use repeated sales data and control for original school district fixed effects in a difference-in-differences framework. Their result shows that within the original school zone, areas zoned to higher-quality schools did not experience increases in price, relative to areas redistricted to lower quality schools. A one standard deviation increase in test scores increases housing prices by 3.2 percent and the municipal district effect is 5.5 percent. 
Our approach most closely follows that of Bogart and Cromwell (2000), Ries and Somerville (2010) and Collins and Kaplan (2017) by taking advantage of a natural experiment - exogenous changes in school boundaries - with difference-in-difference estimation. In this way we avoid concerns about sorting along school boundaries (Bayer, Ferreira, and McMillan, 2007; Kane, Riegg, and Staiger, 2006). Our paper differs from other studies as we are not not capturing the actual impact of school quality change associated with such redistricting on house values but rather the impact of the expected quality change. Second, we split the whole redistricting process further into a pre-approval period and a post-approval period to see how people update their beliefs about where the redistricting will take place and its impact on house prices, contributing to a related literature on information and learning in hedonic evaluations (Cheshire and Sheppard, 2004; Ma, 2019).

\section{The Impacts of Rezoning School Boundaries on Property Values}

As discussed in Section 2, there have been a few studies that consider how changes in district lines or catchment areas affect property values (Bogart and Cromwell, 2000; Collins and Kaplan, 2017; Ries and Somerville, 2010). The primary objective of these studies has been to identify the capitalization of different educational attributes and characteristics into property values. While we, too, use changes in district lines to examine the capitalization of test scores, we are also interested in examining how changes in catchment areas affect social welfare.

Our objective is not to provide neither a technical nor rigorous modeling of housing market equilibrium but rather to provide some intuition to be able to make some statements about the welfare impacts of school boundary changes based on our empirical analysis. Essentially what we argue is that the gross property value can be considered a measure of the willingness of a household to pay for the amenities of a house including educational quality in the catchment area. Then the aggregate social benefits for a given set of school boundaries is simply the sum of the gross residential property values in the city given those boundaries. Then, as we more formally outline below, changes in aggregate residential property values due to changes in school boundaries are a measure of changes in aggregate social benefits and whether the school boundary change is potentially Pareto-improving or not following the Kaldor-Hicks improvement criteria (Hicks, 1939; 
Kaldor, 1939). With this goal in mind, we outline a simple model of equilibrium in the housing markets and the impacts of school boundary changes.

\subsection{An Open City Model}

Consider a simple static model of a open city (school district) consisting of $J$ catchment areas. Each catchment area provides public education with $e_{j}$ being the quality of education in area $j$. There are $N$ households residing in the city with each household i consuming a private good, $\left(x_{i}\right)$, housing $\left(h_{i}\right)$, and the educational quality, $\left(e_{j}\right)$, within the catchment area in which they reside. Households are assumed to be mobile between the $J$ catchment areas as well as between this city and other cities. To reflect zoning restrictions and the existing housing stock, we assume that there are $K$ distinct, discrete levels of housing with $h^{1}<h^{2}<\ldots<h^{k}$ with area $j$ having $s_{j}^{k}$ units of housing quality $h^{k}$. Then the rental value of a unit of quality $h^{k}$ is $P_{j}^{k}=P\left(h^{k}, e_{j}\right)$. Then let utility for household be given

$$
U\left(w^{i}-P\left(h^{k}, e_{j}\right)(1+\tau), h^{k}, e_{j}\right)
$$

Educational quality within catchment area $j$ is assumed to be a function of per-student expenditures $\left(b_{j}\right)$ and a factor specific to the area $\left(I_{j}\right)$ that might include, among other factors, the demographics of the area, and the enrollments, that is, $e_{j}=e\left(b_{j}, I_{j}, N_{j}\right)$. While for this analysis we assume that per-student expenditures across the city are the same and invariant $\left(b_{j}=\bar{b}, \forall j \in J\right)$, educational quality is assumed to increase in the district-specific factor, $\frac{\partial e_{j}}{\partial I_{j}}>0$, and be non-increasing in

enrollment, $\frac{\partial e_{j}}{\partial N_{j}} \leq 0$. We note to close the model we assume the existence of absentee landowners who receive the rents, that is, who own the properties. Of course, in reality, our data is primarily composed of residents who are both owners and occupiers of the property. This does not cause any significant concerns for the results we present here.

\subsubsection{Equilibrium Conditions}

Inter-city mobility requires that, in equilibrium, all households receive at least the level of utility they could receive elsewhere that we denote by $\bar{U}^{i}$ and therefore has no incentive to move. 
Then if household $i$ chooses to reside in a house of quality $h_{j}^{k}$ in area $j$ it follows that

$$
U^{i}\left(w_{i}-P_{j}^{k}, h_{j}^{k}(1+\tau), e_{j}\right) \geq \bar{U}^{i}
$$

and for a house of quality $k$ in area $j$ of the city, $h_{j}^{k}$, can be considered the maximum "bid" for that house. Then letting $\left\{\widetilde{P}_{j}^{k}\right\}$ denote the set of all bids for a house of quality $k$ in area $j$ it follows that

$$
P_{j}^{k}=\max \left\{\widetilde{P}_{j}^{k}\right\}
$$

Then define the aggregate city property value for educational expenditures $b^{o}$ and school catchment areas denoted by $J^{o}$ as

$$
P^{A}\left(b^{o}, J^{o}\right) \equiv \sum_{j \in J^{o}} \sum_{k=1}^{K} P_{j}^{k}
$$

\subsubsection{Net Social Benefit and Catchment Boundary Changes}

Given this description of equilibrium, we can now say something about the changes in educational policy, specifically, the impacts of changes in the school boundaries on property values and welfare.

Proposition 1 Assume that (2) holds with equality. Then let $\left(b^{o}, J^{o}\right)$ represent the (current) level of spending and school catchment boundaries and $\left(b^{\circ}, J^{\prime}\right)$ with associated aggregate property value of $P^{A}\left(b^{o}, J^{o}\right)$ and $P^{A}\left(b^{o}, J^{\prime}\right)$ respectively. Then if:

1) $P^{A}\left(b^{o}, J^{o}\right)>P^{A}\left(b^{o}, J^{\prime}\right)$ the change in catchment area boundaries reduces aggregate property values and therefore decreases aggregate welfare;

2) $P^{A}\left(b^{o}, J^{o}\right)<P^{A}\left(b^{o}, J^{\prime}\right)$, the change in catchment area boundaries increases aggregate property values and therefore increases aggregate welfare;

3) $P^{A}\left(b^{o}, J^{o}\right)=P^{A}\left(b^{o}, J^{\prime}\right)$, the change in catchment area boundaries has no impact on aggregate property values and therefore no impact on aggregate welfare.

Proposition (1) is simply an application of the well-known property of "Tiebout" equilibria, that property value maximization with respect to a public service implies that the public service is efficiently provided (Sonstelie and Portney, 1978). As utility of residents is assumed equal to their next best alternative, the only changes in welfare are associated with changes in property 
value and the additional income for the owners, be they residents of the city or not. Then it follows that a change in catchment is welfare increasing (decreasing) if it increases (decreases) aggregate property value.

Of course, as we explore in our empirical analysis, that aggregate property value increases or decreases does not mean that there are uniform increases within the city. With redistricting we expect that houses redistricted into districts with higher educational quality should increase in value while those redistricted into districts with lower quality should decrease in value.

We further note that the assumption that the change in property values in the areas switched to another catchment area captures the benefits of redistricting relies on the assumption that educational quality in other areas is unaffected. Of course, opening a new school may reduce crowding in existing schools increasing property values in those areas or, if the new school takes the best teachers away from existing schools educational quality might be reduced in the remainder of the school district. In either case, the change in property values in those areas that have switched schools would represent a relative increase (decrease) in property values and benefits, not an absolute increase (decrease). Of course, it follows, then, that if redistricting affects welfare in areas that are not redistricted, Proposition 1 will not strictly hold.

\section{Background of Redistricting in Fayette County}

According to Fayette County Public Schools (FCPS) statistics, there has been an average increase in enrollment of 600 to 750 students a year in the school district for the past ten years. To accommodate this growth, a redistricting process began in 2013 in anticipation of a new high school in 2017. The year-long work of drawing new school boundaries began in spring 2014 with a committee of parents, teachers, Fayette County Public School administrators, two school board members, a district Equity Council representative, a city planning official, a home builder and other community stakeholders. The committee met three times to review some initial demographic information and community growth trends. In April 14, 2015, the committee presented a plan to the Fayette County Board of Education with a summary of its draft proposals. The school board then met with the redistricting committee on April $21^{\text {st }}$ for a joint work session. At their June 3, 2015 meeting, The Fayette County Board of Education approved the redistricting plan. 
Figure 1 shows the map of the original school catchment areas and the proposed plan. The locations of each high school is labeled on the map. Under the new plan, Bryan Station still covers a large proportion of Fayette County but the southeast part was redistricted to the proposed school. There are not large geographical changes in the other four school catchment areas. The overlapped map in Figure 2 indicates how the boundaries change. The dashed line represents the old school district boundaries and red solid line represents changes in school district boundaries from the redistricting. Based on these changes, we are able to determine the school catchment area for each house sold before and after the redistricting process.

Housing sales data from Fayette County Property Valuation Office (PVA) comes with an address for each sale record. Using ArcGIS we match each sale with a high school catchment area. ${ }^{6}$ As mentioned, our data from 2003 to August 2017 are prior to the implementation of the the new school district plan. For our purposes, all the sales prior to June 3, 2015, the approval date for the redisticting proposal, are in the "old" catchment area - the actual school catchment areas for all sales. Based on the redistricted map and location of each house, we define the "new" school catchment area, reflecting the proposed boundary changes, which is relevant for all sales after June 3, 2015. Table 1 shows sales transactions categorized into old and new school catchment areas. Of the 13,823 houses sold in the Bryan Station area during the years of study, 7,153 sales are within both old and new Bryan Station area while 1,079 sales occurred in the area to be redistricted to the Paul L. Dunbar High School and 5,591 sales were in the area to be in the proposed school (Frederick Douglass) catchment area. The second largest change was in the Henry Clay High School catchment area where 7,268 of the 10,920 sales were located in the Henry Clay area, 1,290 of the sales were in the Tates Creek catchment area and 2,342 transactions were in the catchment area of the proposed high school. Lafayette High School catchment area was subject to redistricting to both the Henry Clay and proposed high school catchment areas, but with only a few sales in the latter.

\footnotetext{
${ }^{6}$ The geographic coordinates for all Fayette county addresses are available from the Lexington Fayette Urban County Government.
} 


\section{Empirical Strategy and Data}

A conventional way of modeling the marginal willingness to pay of school quality is hedonic estimation. It uses the following reduced-form regression:

$$
\ln P_{i j}=X_{i}^{\prime} \beta+Z_{i}^{\prime} \delta+S_{j} \cdot \gamma+u_{i j}
$$

where $P_{i j}$ is sale price of a house $i$ in school catchment area $j, X_{i}$ is a vector of housing attributes and $Z_{i}$ represents locational characteristics. $S_{j}$ is a measure of school quality, usually observed by test scores and $\gamma$ delivers the marginal willingness to pay for a unit increase in school quality. $u_{i j}$ is the error term which is assumed to be independent from school quality. However it suffers omitted variable bias if there is unobserved effect in $u$ such as neighborhood characteristics that cannot be measured or if sorting behavior exists where people choose a school with added-value not derived from quality (Black, 1999; Gibbons, Machin, and Silva, 2013).

As discussed in Section 2 one approach used to address these unobserved neighborhood effects is to estimate a boundary fixed effects model only using a narrow band of properties along the school boundaries (Black, 1999). While numerous studies since Black (1999) have used the boundary fixed effect approach, the approach we follow is a difference-in-differences estimator employing a change in school boundaries as the exogenous treatment.

\subsection{Difference-in-Differences}

We exploit a natural experiment arising from school boundary changes to examine the capitalization of school quality ${ }^{7}$. In essence, we are looking at the same house before and after the announcement of redistrictings though we are not using repeated sales as in Ries and Somerville (2010) but pooled cross-sections. Our identification comes from variation in expected school quality. As school quality of the existing high schools, at least as measured by ACT scores and funding, has not significantly changed during the time of our study, we are able to capture how redistricting affects housing prices through expectations on future school quality through announced, but not yet implemented, boundary changes. Our focus is on estimating the impact of expected school

\footnotetext{
${ }^{7}$ Black and Machin (2011) and Machin (2011) provide a summary of major empirical approaches that deal with those issues, including regression discontinuity, instrumental variables, and difference-in-differences methods.
} 
quality on capitalization by exploiting boundary changes that include creating a catchment area for a proposed school, has not been addressed in the literature focused on using contemporaneous test scores (or moving averages) to determine the extent that school quality is capitalized into housing prices.

Our treatment group comprises all "catchment-switching" houses - houses that were sold in a (high school) catchment area that is different from the future, redistricted catchment area. In contrast, our control group is "non-switching" houses, housing sales with no change in future catchment area as a result of redistricting.

Formally, let Treat $_{i j}$ be a dummy variable indicating the treatment status of house $i$ in school catchment area $j$ that equals one if a house will be in a new catchment area after redistricting is implemented - these are the "switchers". In Table 1, the control group are the diagonal representing those non-switching house sales. We also define a binary variable Post $t_{i t}$ that equals one if a house $i$ sold in year $t$ was after the approval of redistricting plan and equals zero if sold before. Using a difference-in-differences (DD) approach we estimate the impact of changing school catchment area boundaries on housing prices. Then letting $\ln P_{i j t}$ denote the log of sale price of house $i$ in catchment area $j$ at time $t$, we estimate

$$
\ln P_{i j t}=X_{i j t}^{\prime} \beta+Z_{i j t}^{\prime} \delta+\phi \cdot \text { Treat }_{i}+\psi \cdot \text { Post }_{i t}+\theta \cdot \text { Treat }_{i} \cdot \text { Post }_{i t}+u_{i j t} .
$$

where $\theta$ represents the effect of switching catchment areas on housing prices and should be interpreted as the effect of all aspects of how schools affecting property values and underlying preferences. Specifically, we have not included any separate measures of educational quality in (6) but in Section (6.2) we consider how the redistricting affects the impact of current test scores on housing prices. Then comparing expected pre- and post-treament housing prices for houses in the control group we have

$$
\begin{aligned}
& \mathrm{E}\left[\ln P_{i j 1}^{0} \mid \text { Treat }_{i}=0\right]-\mathrm{E}\left[\ln P_{i j 0}^{0} \mid \text { Treat }_{i}=0\right] \\
& =\left(X_{i j 1}^{\prime}-X_{i j 0}^{\prime}\right) \cdot \beta+\left(Z_{i j 1}^{\prime}-Z_{i j 0}^{\prime}\right) \cdot \delta+\psi
\end{aligned}
$$

Analogously, the expected change in sale price for treatment group before and after the approval 
of redistricting is:

$$
\begin{aligned}
& \mathrm{E}\left[\ln P_{i j 1}^{1} \mid \text { Treat }_{i j}=1\right]-\mathrm{E}\left[\ln P_{i j 0}^{1} \mid \text { Treat }_{i j}=1\right] \\
& =\left(X_{i j 1}^{\prime}-X_{i j 0}^{\prime}\right) \cdot \beta+\left(Z_{i j 1}^{\prime}-Z_{i j 0}^{\prime}\right) \cdot \delta+\psi+\theta .
\end{aligned}
$$

The difference of the two groups then is:

$$
\begin{aligned}
& \left(\mathrm{E}\left[\ln P_{i j 1}^{1} \mid \text { Treat }_{i}=1\right]-\mathrm{E}\left[\ln P_{i j 0}^{1} \mid \text { Treat }_{i}=1\right]\right) \\
& -\left(\mathrm{E}\left[\ln P_{i j 1}^{0} \mid \text { Treat }_{i}=0\right]-\mathrm{E}\left[\ln P_{i j 0}^{0} \mid \text { Treat }_{i}=0\right]\right) \\
& =\theta .
\end{aligned}
$$

Then by double-differencing the treatment and control group average effect, we obtain the price effect of redistricting on houses for a specific school catchment area $j$,

$$
\Delta \ln P_{j}=\theta
$$

The key identifying assumption of difference-in-differences model is common trends. It implies that in the absence of the redistricting approval, the potential log prices of houses in the treated group would have followed the same trend as log prices in the control group. Under this assumption $\theta$ will identify the average treatment effect on the treated. Figure 5 provides evidence to support the assumption. To construct this figure, we first pool all transactions over the years to run a regression of log price on a set of covariates, controlling for house characteristics, distance to urban boundary, city center, and nearest park, and also current school catchment area fixed effect. Then we predict the residuals for each sale and collapse them at quarterly level. Next we plot residuals against time using local polynomial regressions (Fan and Gijbels, 1996). Houses that are located in catchment area that is going to be redistricted follows a similar trend comparing to houses that are staying in the same catchment area. Nevertheless, housing prices in treatment group seem to be lower, while after the second quarter of 2015, it overtakes control group. 


\subsection{Data and Summary Statistics}

\subsubsection{Housing Data}

Our housing price data comes from the Fayette County Property Valuation Administrator (PVA). ${ }^{8}$ It includes general characteristics of all parcels matched to a sales data set. The sales data set records all transactions from January 2003 to August 2017. For each house, we have its physical characteristics including the number of bathrooms, square footage, fireplaces, and exterior finish along with its transaction history (e.g. sale date, price, and sale type). We choose the arm's length transactions of single-family residential houses and drop the top and bottom one percent of observations based on prices to eliminate the impact from extreme values. Column (1) - (5) of Table 2 shows the summary statistics of all houses in each school catchment area that were sold during this time period. The Henry Clay and Paul L. Dunbar catchment areas have the most expensive homes but these homes also tend to be larger, have more bathrooms and are more likely to have brick finishes. In contrast, Bryan Station has both the least expensive and smallest houses. It is worth noting that houses sold in Bryan Station are average a distance of 3.3 miles from the high school, almost double the distance for homes in the Tates Creek and Paul L. Dunbar catchment areas. In Figure 3 we plot the median price of sales for each school catchment area between 2003 and 2017.

In columns (6) and (7) of Table (2) we divide sales into treatment and control groups. Doing so, we do not see a large difference in terms of sales price, square footage, stories and, bathrooms. Not surprisingly, the most significant difference in the distance measures between the two groups is distance to school. While house age, number of full bathroom, exterior finish (brick) are different, it does not suggest that redistricting was influenced by the characteristics of the housing stock. While there may be potential cross-school differences for treatment and control houses, there is no evidence of differences in housing characteristics between non-switching houses and switching houses within the same old catchment areas, that is, a house being redistricted from current catchment area to another catchment area is exogenous to its characteristics.

\footnotetext{
${ }^{8}$ See https://fayettepva.com for more on the Fayette County PVA.
} 


\subsubsection{School Quality}

While it is not necessary to have school test scores data to quantify school quality premiums with our empirical strategy, we follow the literature and obtain data on the mean ACT test score in each of the high schools between 2003 and 2017. ${ }^{9}$ Dills (2004) finds evidence that housing values do in fact respond to ACT scores. Figure 4 presents the annual average ACT composite scores for each school by year. It is clear that Bryan Station has significantly lower scores than the other high schools in all tested subjects. The other four schools have relatively similar scores except for 2009 and 2011 where we see a spike at Paul L. Dunbar High School. Similar to differences in ACT scores across the high schools, Figure 3 shows consistency in differences in housing price across the school catchment areas. Comparing with the trends in house price differences between the catchment areas and the ACT scores (Figure 4), the housing price differential between the Henry Clay and Paul L. Dunbar, relative to the gap in test scores, has been widening. In contrast, though Lafayette and Tates Creek performed differently in test scores, their housing prices moved together.

One concern with using ACT scores to measure school quality is the possibility of selection bias - the students taking the exam might not be a representative sample of all students in the school. As of 2007-2008 school year all Kentucky juniors are required to take the ACT, dramatically reducing concerns about selection bias. Based on the school report cards we obtained, the percentage of students tested does not vary much across schools or years with more than 98 percent of high school students in Fayette county taking the ACT during our sample period.

\section{Results}

Here we discuss the results of estimating (6) as well as extensions of it. We first show that without controlling for school test scores, the unconditional catchment-switching effect is, on average, increasing sale prices for homes scheduled to change high schools in 2017. Then we follow Black (1999) using common school boundaries to eliminate unobserved neighborhood effects and find that the redistricting announcement disrupt the relationship between current school quality, as measured by current ACT scores, and housing prices. We further include test scores in our

\footnotetext{
${ }^{9} \mathrm{ACT}$ test scores are available from the Kentucky Education Department, see https://education.ky.gov/AA/Acct/Pages/Proficiency.aspx.
} 
difference-in-differences specification to see whether actual school quality has effect on housing prices after redistricting. While current ACT scores had significant effect on housing price prior to the redistricting announcement, after the announcement the effect was dramatically attenuated and insignificant. Next we examine how the impact of the redistricting may differ for different school pairs and find a non-negative effect on sales prices of the "switching" houses in each of these school pairs. To better assess the distribution of the benefit of these boundarys changes, we conduct a triple-differences (DDD) estimation to see what type of houses gain most from this redistricting. Results show that larger houses benefit more from being redistricted. Finally, we test to determine whether the capitalization of redistricting varies with the certainty of the plan.

\subsection{Unconditional Switching Effect}

Table 3 provides the pooled OLS regression results under several alternative specifications. Column (1) includes house characteristics, distance measures, and policy variables. Column (2) (6) add different controls for school catchment area, census tract, year, and census tract by year fixed effects. The coefficients for the house characteristics have expected signs and are significant in all specifications. In our preferred specification (column (6)), square footage positively affects housing value, house age affects the price quadratically, an additional full bathroom increases the price by thirteen percent while an additional half bathroom leads to a 7.2 percent increase, and all brick and part brick houses cost 9.2 percent and 4.3 percent higher than other houses. However, distance measures are not a significant determinant of sale price when we control for location and time.

The coefficient on Treat variable is not significantly different from zero in all specifications implying that, on average, houses in areas proposed to switch high school catchment areas are not systematically higher in value than houses that remain in the same catchment area. The coefficient on Post of 1.8 (percent) indicates appreciation for both switching and non-switching houses. Estimates of the coefficient on the interaction term Treat Post suggests that houses redistricted to a different school catchment area increase 2.4 percent in price on average. When considering these results, keep in mind that the coefficient estimates from the pooled regressions are the effect

of redistricting in all five school catchment areas with the coefficient on Treat Post aggregating the switching effects between different school catchment areas. This aggregation or, averaging, of 
the impacts of boundary changes is likely to mask the differential effects of individual boundary changes, some of that may be positive and some that may be negative. In Section 6.3, we examine the differential impact of the redistricting process on each school area.

\subsection{Test Scores Effect}

One explanation for the impact of redistricting on property values found from estimating (6) is the change in expected school quality for those houses scheduled to be redistricted. The results in Table 3 show the unconditional effect, which controls for the original school catchment area fixed effect without including test scores. To better understand the impacts of redistricting on property values, we next estimate the relationship between test scores (ACT) and property values. Our particular interest is on how the impact of test scores on property values may change after the announcement of redistricting.

We follow Black (1999), among others, to control for the school attendance using a boundary fixed effect approach to isolate the effects of school quality on property values from other shared amenities along school boundaries. There are five schools in Fayette county and we have a total of seven boundaries by pairing shared boundaries. These bordery pairs capture those unobserved characteristic within a similar neighborhood but different catchment areas. As we have a repeated cross-section following Dhar and Ross (2012) and Dachis, Duranton, and Turner (2012) we include fixed effects for each school/border to control for sorting and resulting demographic differences along school boundaries (Bayer, Ferreira, and McMillan, 2007; Kane, Riegg, and Staiger, 2006). We separately estimate repeated cross-sectional regressions using observations within $k$ miles from the common boundary for sales before and after the boundary change. Between June 2015 and August 2017, the new school attendance boundary had been approved but not yet taken effect and home buyers still sent their children to the current schools. If the coefficients on test scores significantly differs before and after the approval of the redistricting proposal, then it would indicate a change in home buyer's preference. If a static housing price model correctly reflects the marginal willingness to pay for school quality, then these coefficients should not differ and all the change in price should be attributed to the expected quality change of school district. We express our estimating equation as a simple cross-sectional hedonic as in (5) in which, as mentioned, the sample is restricted to sales within $k$ miles of the seven boundaries and run separately for sales prior to and after the June 
2015 announcement of redistricting.

Table 4 presents the results of our estimation. Column (1) reports coefficient estimates when we include all sales within Fayette County and do not control for boundary fixed effects while in columns (2) - (5) we select sales within 0.4 miles to 0.1 mile increments from each boundary controlling for school/boundary fixed effects. Column (6) does not include a school/boundary fixed effect. In general, we find that before the redistricting proposal increases in ACT composite test scores increase housing prices. In contrast to Black (1999) and Bayer, Ferreira, and McMillan (2007) among others, the coefficient we estimate on test score without controlling for boundary fixed effects (columns (1) and (6)) are not significantly greater than the estimated coefficients when we control for the boundary fixed effect. As we further restrict our attention on houses near the boundary, the test score has a greater impact on prices before the redistricting approval. Within 0.1 mile from the boundary, a one point increase in school ACT test score will increase house prices by 5.6 percent.

Approval of the redistricting plan seems to attenuate the impact of ACT scores. Panel B shows that after the announcement of the redistricting plan, we see a similar impact of school quality on housing price for the entire, post-announcement sample with an average 2.7 percent premium associated with one point increase in test scores. However, after approval of redistricting, the effect along the boundaries are reduced and insignificant - consistent with future school options, with potentially different school quality, along these borders. More importantly, test scores do not provide significant explanation for differences in housing values along school boundaries that have not changed during the period in which redistricting has been approved but is not yet operational.

An alternative to identifying the pre- and post-announcement effects of test scores on housing prices using a boundary fixed effect approach is to estimate a difference-in-difference model. Modifying (6) to include test scores with the potentional for differential effects before the annoucement of redistricting, gives

$$
\ln P_{i j t}=X_{i j t}^{\prime} \beta+Z_{i j t}^{\prime} \delta+\gamma S_{j t}+\phi \cdot \text { Treat }_{i}+\psi \cdot \text { Post }_{i t}+\rho S_{j t} \cdot \text { Post }_{i t}+\theta \cdot \text { Treat }_{i} \cdot \text { Post }_{i t}+u_{i j t} .
$$

where $S_{j t}$ is the mean ACT for school $j$ in year $t .^{10}$

\footnotetext{
${ }^{10}$ We also estimated a triple difference (DDD) with respect to the test score, $\ln P_{i j t}=X_{i j t}^{\prime} \beta+Z_{i j t}^{\prime} \delta+\gamma S_{j t}+\phi \cdot$ Treat $_{i}+$
} 
Table 5 shows the results from estimating alternative specifications of (11). Columns (1) and (2) are pooled cross-sectional regressions; in column (1) we report the results when we do not control for school fixed effects. From column (1), a one point increase in current test scores on average is associated with 2.5 percent increase in housing price. In contrast, in column (2) when the school-fixed effect is included, the estimate of the test score on housing prices is insignificant and essentially zero - the effect of the test score is "fully absorbed" by school fixed effect. Column (3) reports the estimates where we use current test scores as an intensity measure of the treatment and interact it with Post to see whether the school quality, as measured by the ACT score, of "old" school zoning still affects housing prices. The coefficient on Score Post is 0.4 (percent) but is statistically insignificant. Intuitively this insignificance is expected as the current score in the "old" school may not be a good predictor of the score in the new school. However, adding the switching effect corrects people's expectation. The estimate of the interaction term Treat Post $(\theta)$ is 2.6 percent, slightly higher than 2.4 percent in Table 3 and echoes the results found in Table 4 .

\subsection{Disaggregating the Impacts of Redistricting}

The redistricting proposal involved every high school in Fayette County. Where redistricting means a change in future high school we expect the demand for housing and therefore housing prices to change. In Table 3, which reports the results when all boundary changes (Bryan Station to Frederick Douglas, Henry Clay to Frederick Douglas, Bryan Station to Dunbar, etc.) are pooled, properties scheduled to be redistricted appreciated by 2.4 percent, which we interpret as an average effect. However, the impact of changes in school boundaries are unlikely to be the same - those houses redistricted to what are considered higher-performing schools should appreciate while those houses redistricted to a lower-performing schools should, ceteris paribus, depreciate. To address the likelihood of heterogenous impacts of these boundary changes, rather than pooling all sales, we disaggregate them into redistricting pairs and run separate DD estimation of each pair to examine heterogenous effects of school boundary changes.

We report these results in Table 6. Each column is a regression following (6) using all sales from a single school catchment area. Our focus is on the interaction term, Treat $\cdot$ Post, the DD

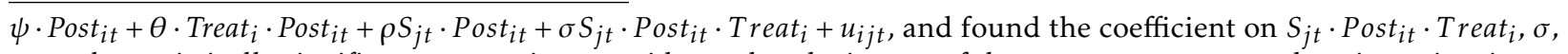
not to be statistically significant, suggesting no evidence that the impact of the current test score on housing prices is not different in the redistricted areas from those that were not after post-announcement of redistricting. 
estimate of housing price changes for houses in redistricted area post-announcement. Inspection of the coefficient on Treat . Post across the columns does indeed indicate heterogenous impacts of redistricting with the most pronounced effects being appreciation for houses redistricted to the proposed school (Frederick Douglas). Columns (1), (3), and (5), respectively, show the effect of being redistricted to the proposed school for houses previously in the catchment areas for Bryan Station, Henry Clay, and Lafayette. Being redistricted from Bryan Station to the proposed school catchment area leads to a 6.6 percent increase in housing price on average and is highly significant. Being redistricted from Henry Clay to the proposed school results in appreciation of 2.2 percent. While the effect of being redistricted from Lafayette to proposed school is quite large (10.4\%), the sample of redistricted properties is small and the coefficient on Treat Post is only marginally significant. Confirming our expections about school quality of the respect high schools, being redistricted from Bryan Station to Paul L. Dunbar results in a 2.2 percent increase in housing price relative non-switchers in Bryan Station.

These results are also consistent with Cheshire and Sheppard (2004), where it is argued that uncertainty plays an important role in determining expected school quality and hence expected housing value. Because both the quality of a school could change and boundaries could be redefined, home buyers face uncertainty. Cheshire and Sheppard (2004) estimates show that for houses located in periphery areas with new construction the value of educational quality is discounted by more than 40 percent relative to houses in other parts of the city. Given that Henry Clay is a considered a high-performing school and as the new school (Frederick Douglas) was not built yet, there is a risk of no longer being in an area with a good school, possibly explaining why the increases in sales prices there are smaller than for houses redistricted from Bryan Station to the proposed school. Further, as property values in the Henry Clay area are higher than Bryan Station, the smaller percentage increases in property values should not be entirely unexpected. The remaining boundary changes as a result redistricting are positive though some are quite small and insignificant but none of them is significantly negative. These nonnegative results are in contrast to Bogart and Cromwell (2000) finding of an average decrease of 9.9 percent in housing values in those areas which changes catchment areas. Our results show that redrawing the school attendance boundaries in Fayette County have benefitted houses to be redistricted not only in the aggregate level, but also for each of the individual high school catchment area changes 


\subsection{Who Benefits from the Boundary Change?}

The previous difference-in-differences results show that, on average, there exists a relative increase in prices for houses sold in locations scheduled for redistricting. To gauge the magnitude of this redistricting plan on aggregate house values and tax revenue, we use property assessment data in 2013 , one year before the start of redistricting process, to calculate the total gain in property values. We focus on houses that will be redistricted to the new school catchment area and multiply the 2013 value by the corresponding coefficient we find in the bottom line in Table 6 . The results are listed in Table 7. The total increase in the housing stock value in Bryan Station is more than 85 million dollars from around 8,000 houses that will be redistricted into the proposed area. Henry Clay also has substantial increase around 15 million dollars. Though Lafayette has the largest estimate (10.4\%) from previous section, but due to lower average house value and fewer houses, the total gain is less than the other two catchment areas. But the aggregate impact of the new school is large. The total value of housing stock in the three catchment areas amounts to more than 2 billion dollars and change of value is around 108 million dollars, an increase, on average, of $\$ 9016$ per house. If we annualize the benefits over a 15 year period at a discount rate of 3.5\%, this is a benefit of $\$ 783$ per year per household. The estimated construction cost of the new high school was 82 million dollars ${ }^{11}$ though this cost does not include any additional costs associated with maintenance of new facilities or any other costs not strictly a function of enrollments. As discussed in Section (3), to the extent that adding the new high school (Frederick Douglass) affects educational quality in the other high schools, the change in value is a measure of the relative benefits of the new school, not the absolute benefits.

\subsubsection{Differential Effects of Redistricting by House Size}

Could this benefit we have found merely indicate there also exists losers? Though we are not able to calculate the relative change of such a policy on houses that will stay in original school catchment area, we can investigate what type of houses benefit from such redistricting through a triple-differences (DDD) analysis. We should expect larger families to benefit more from redistricting to what is considered a better school and, therefore, larger houses should appreciate

\footnotetext{
${ }^{11}$ See Kennedy, Mike “\$82 million high school opens in Lexington, KY” American School \& University (August 8, 2017), https://www.asumag.com/new-construction/82-million-high-school-opens-lexington-ky.
} 
more as the family size is correlated with the house size. Our specification has the following form:

$$
\begin{aligned}
\ln P_{i j t}=W_{i j t}^{\prime} \beta+Z_{i j t}^{\prime} \delta+\phi \cdot \text { Treat }_{i}+\psi \cdot \text { Post }_{i t}+\theta \cdot \text { Treat }_{i} \cdot \text { Post }_{i t} \\
+\tau \cdot \text { Size }_{i}+\eta \cdot \text { Treat }_{i} \cdot \text { Size }_{i}+\xi \cdot \text { Post }_{i t} \cdot \text { Size }_{i}+\zeta \cdot \text { Treat }_{i} \cdot \text { Post }_{i t} \cdot \text { Size }_{i}+u_{i j t}
\end{aligned}
$$

where $W$ is the same set of control variables as $X$ excluding Size, which is a measure of house $i$ size. We employ two alternative measures of house size: a) the number of full bathrooms and b) the log of square footage. The parameter $\zeta$ then implies the relative change of a larger house comparing to a smaller house in the treatment group after the approval of redistricting plan.

The first set of results with the number of full bathrooms to indicate size is found in Table 8 . Our parameter of interest is $\zeta$, the coefficient on $\operatorname{Treat}_{i} \cdot \operatorname{Post}_{i t} \cdot \operatorname{Size}_{i}$. For the majority of redistricted areas, we see a positive effect of house size on the effect of anticipated redistricting albeit with only three of the eight areas having statistically-significant, positive coefficients. Of those areas redistricted to the proposed high school only for Henry Clay is the estimate of $\zeta$ statistically significant. The exception to positive effects of house size on the value of redistricting is in the area that is redistricted from Lafayette to Henry Clay, which has a 3.7 percent decrease (per bathroom) in house values for larger houses. Similar results are also found in a second set using log(square footage) as the measure of size. However, with this measure we do not see any strong negative values for $\zeta$.

A possible explanation for the negative coefficient on $\zeta$ in the area redistricted from Lafayette to Henry Clay could be the systematic preference for smaller houses in Lafayette catchment area. The summary statistics of house characteristics in column (3) of Table 2 shows that compared to the other schools, houses in Lafayette are substantially smaller and have fewer bathrooms and fireplaces.

\section{Extensions and Tests of the Model}

\subsection{Information Updating}

Recent studies (Ma, 2019; Cheshire and Sheppard, 2004) suggest that learning has been an important factor that potentially biases hedonic estimates. In regard to our DD estimates, there 
might be concerns that some people have anticipated redistricting prior to its passage (June 2015) as the Fayette County Public Schools (FCPS) announced its intention to redraw school boundaries on April 29, 2014. If the boundary changes were anticipated prior to June 2015 we could have a downward bias on the coefficient on Treat Post our measure of the impact of redistricting on housing prices. To address this issue, we add a period between the day FCPS announced the redistricting process (April 29, 2014) and the day the plan was officially approved (June 3, 2015). Specifically, let $T_{i}, i=1,2$ be the timing of announcement and approval date respectively. Also define two new binary variables indicating the period of a house sold at time $t$, Post $_{1}$ is equal to

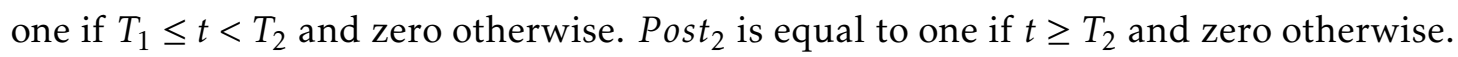

$$
\ln P_{i j t}=X_{i j t}^{\prime} \beta+Z_{i j t}^{\prime} \delta+\phi \cdot \text { Treat }_{i}+\kappa \cdot \text { Post }_{1}+\lambda \cdot \text { Treat }_{i} \cdot \text { Post }_{1}+\psi \cdot \text { Post }_{2}+\theta \cdot \text { Treat }_{i} \cdot \text { Post }_{2}+u_{i j t}
$$

where $\lambda$ captures the premium of information received by home buyers between the day when FCSC announced that redistricting was to be considered and the approval date of the plan. The term $\theta$ captures the "net" impact of approval of the redistricting plan. In the absence of an information effect, that is no anticipation of redistricting changes we expect $\lambda$ to equal zero. Column (1) of Table 10 reports the results of estimating (13) using all observations. In general, with this sample the information premium does not have an important impact. However, the net benefit of redistricting, the coefficient on Treat. Post 2 , is large (3.1 percent) compared to the estimate from our base model, (2.4 percent) though it is statistically insignificant. Column (2) - (8) report the results of separate regressions performed using a sample from a single catchment area. Similar to the previous result, values of houses redistricted out of Bryan Station increased in value. Sale prices increased, on average, by 7.1 and 3.9 percent for transactions that took place in the catchment areas for the proposed school and Paul Dunbar High School in the post-approval period, larger than the DD estimate of 6.6 and 2.2 percent reported in Table 6. For the Henry Clay High School catchment area, we also observe a 4.2 percent increase in house values redistricted to the proposed school and an insignificant but positive effect for houses that will be in Tates Creek. Only redistricting from Paul Dunbar to Lafayette and from Tates Creek to Henry Clay show negative net impact in the post-approval period. Overall we find that the results reported in Table 10 are still consistent with what we found in when estimating the boundary fixed effect models with a single post-approval 
period (Table 6) - that there is no significant negative benefit associated with boundary changes.

However, we do see significant pre-approval effects among school areas with large (and significant) pre-approval positive appreciation for houses redistricted from Henry Clay to the proposed school and a smaller, postive pre-approval effect on houses redistricted from Henry Clay to Tates Creek. Negative and significant pre-approval treatment effects are found for houses redistricted from Dunbar to Lafayette and Tates Creek to Henry Clay ${ }^{12}$. Even if some the estimates of preapproval treatment effects are not significant, they reduce measured net benefit so the estimates our base model ((6) and Table 3) are smaller than when pre-approval impacts oare considered. Without considering people updating their beliefs will not only bias the results downward, but also the opposite direction (Ma, 2019).

\subsection{Placebo Test}

Last, to assess validity of our difference-in-differences approach, we implement a placebo test with results provided in Table 11. In this exercise, we randomly draw a new treatment group from those sales that are not affected by the policy change in each school catchment area from a uniform distribution. Then we discard the true treatment groups and run regressions on the false treatment and true control group for each old school catchment area. The results are found in Table 11. The coefficients on Treat - Post in each school area regressions are not statistically different from zero, suggesting our results are unlikely to be biased.

\section{Conclusion}

Using the exogeneous shock of school redistricting process in Fayette County, Kentucky, we are able to identify the house values change of switching from one school catchment area to another. Our estimates suggest that on average prices of houses being redistricted will increase by 2.4 percent after the approval of the redistricting plan but the extent of appreciation differs across redistricting pairs. Houses in the lowest-performing school (as measured by ACT scores) that are redistricted to the new school appreciate by 6.6 percent relative houses that are not redistritcted, equivalent to a price increase of $\$ 8,212$ using the mean price of the original catchment area. While

\footnotetext{
${ }^{12}$ Lafayette to Henry Clay is not significant in pre-approval period. However, we have very few observations in Lafayette so it is hard to make a valid inference.
} 
being redistricted into a new catchment area poses some uncertainty, in contrast to Bogart and Cromwell (2000) we do not find any significant negative impacts from redistricting on house values. Following conventional approach we apply boundary fixed effect model to examine the impact of test scores on house prices and find that the change of boundaries disrupts existing valuation of school quality near the boundaries. We also derive a series of tests to on how expectations of school quality are capitalized into housing prices. A triple-differences model is used to see the heterogeneous impact of redistricting plan on different types of houses, specifically houses that differ in size. Because household size (number of children) is correlated with house size, we expect to find stronger effects from redistricting in larger houses.

By adding a pre-approval period, we are able to compare the net change of housing price under the actual treatment effect with the price change caused by anticipation before people know the exact change of new plan. Our results show that people do respond to such an information shock and by controlling for anticipation, the benefit of being redistricted will increase the price more. We also test whether the school quality change causes the increase in housing prices and the regression results show that people behave similarly in response to the test scores change and thus the majority of the variations in housing price change can be explained purely by the redistricting treatment. Our results also provide evidence to support the Kane et al. (2003) finding that housing price volatility does not respond to short run test score changes. We find no significant negative effect on house prices if more information is presented to households over time (Figlio and Lucas, 2004).

As we consider redistricting of houses to a proposed, not operating school, the appreciation from redistricting to the proposed school (Douglass) is presumably an indication of the expected increase in school quality. As Frederick Douglass High School became operation in August 2017, an interesting future extension would be to compare the sales prices in the Douglass catchment area prior to the school's opening to sales prices following its actual operation. While at this moment the post-opening sales data is limited, this comparison would provide an interesting comparison of expected and realized school quality on property values.

Another possible extension is to consider how this redistricting and, in particular, the opening of the new high school affect demographic composition. As suggested by Bayer et al. (2007); Kane et al. (2006) and Dhar and Ross (2012) while neighborhoods on opposite sides of a school boundary 
might initially have very similar dynamics, if the schools significantly differ in quality we might expect sorting based on preferences and income to lead to significant differences in demographics along school boundaries. This redistricting will provide an opportunity to see if and how the demographics of neighborhoods on each side of this new school boundary evolve. 


\section{References}

Bayer, Patrick, Fernando Ferreira, and Robert McMillan (2007). A Unified Framework for Measuring Preferences for Schools and Neighborhoods. Journal of Political Economy 115(4), 588-638.

Black, Sandra E. (1999). Do Better Schools Matter? Parental Valuation of Elementary Education. Quarterly Journal of Economics, 577-599.

Black, Sandra E. and Stephen Machin (2011). Housing Valuations of School Performance. Volume 3 of Handbook of the Economics of Education, pp. 485 - 519. Elsevier.

Bogart, William T. and Brian A. Cromwell (1997). How Much More Is A Good School District Worth? National Tax Journal 50(2), 215-232.

Bogart, William T. and Brian A. Cromwell (2000). How Much Is a Neighborhood School Worth? Journal of Urban Economics 47(2), 280 - 305.

Bonilla-Mejía, Leonardo, Esteban Lopez, and Daniel Mcmillen (2018). House Prices and School Choice: Evidence from Chicago’s Magnet Schools Proximity Lottery.

Cellini, Stephanie Riegg, Fernando Ferreira, and Jesse Rothstein (2010). The Value of School Facility Investments: Evidence from a Dynamic Regression Discontinuity Design. Quarterly Journal of Economics 125(1), 215-261.

Cheshire, Paul and Stephen Sheppard (2004). Capitalising the Value of Free Schools: The Impact of Supply Characteristics and Uncertainty. The Economic Journal 114(499), F397-F424.

Clapp, John M., Anupam Nanda, and Stephen L. Ross (2008). Which School Attributes Matter? The Influence of School District Performance and Demographic Composition on Property Values. Journal of Urban Economics 63(2), 451-466.

Clapp, John M. and Stephen L. Ross (2004). Schools and Housing Markets: An Examination of School Segregation and Performance in Connecticut. Economic Journal 114(499), F425-F440.

Collins, Courtney A. and Erin K. Kaplan (2017, May). Capitalization of school quality in housing prices: Evidence from boundary changes in shelby county, tennessee. American Economic Review 107(5), 628-32. 
Dachis, Ben, Gilles Duranton, and Matthew A. Turner (2012, March). TheEffects of Land Transfer Taxes on Real Estate Markets: Evidence from a Natural Experiment in Toronto. Journal of Economic Geography 12(2), 327-354.

Dhar, Paramita and Stephen L. Ross (2012). School District Quality and Property Values: Examining Differences Along School District Boundaries. Journal of Urban Economics 71(1), 18 - 25.

Dills, Angela K. (2004, jan). Do Parents Value Changes in Test Scores? High Stakes Testing in Texas. Contributions in Economic Analysis \& Policy 3(1).

Downes, Thomas A. and Jeffrey E. Zabel (2002). The Impact of School Characteristics on House Prices: Chicago 1987-1991. Journal of Urban Economics 52(1), 1-25.

Epple, Dennis and Richard Romano (2003). Neighborhood Schools, Choice, and the Distribution of Educational Benefits. In Caroline M. Hoxby (Ed.), The Economics of School Choice, pp. 227-286. University of Chicago Press.

Fan, Jianqing and Irene Gijbels (1996). Local Polynomial Modelling and Its Applications: Monographs on Statistics and Applied Probability, Volume 66. CRC Press.

Figlio, David N. and Maurice E. Lucas (2004). What's in a Grade? School Report Cards and the Housing Market. American Economic Review 94(3), 591-604.

Gibbons, Stephen and Stephen Machin (2003). Valuing English Primary Schools. Journal of Urban Economics 53(2), 197-219.

Gibbons, Stephen and Stephen Machin (2006). Paying for Primary Schools: Admission Constraints, School Popularity or Congestion. Economic Journal 116, 77-92.

Gibbons, Stephen, Stephen Machin, and Olmo Silva (2013). Valuing School Quality Using Boundary Discontinuities. Journal of Urban Economics 75, 15 - 28.

Hicks, John R. (1939). The Foundations of Welfare Economics. The Economic Journal 49(196), $696-712$.

Kain, John F. and John M. Quigley (1970, jun). Measuring the Value of Housing Quality. Journal of the American Statistical Association 65(330), 532. 
Kaldor, Nicholas (1939). Welfare Propositions of Economics and Interpersonal Comparisons of Utility. The Economic Journal 49(195), 549-552.

Kane, Thomas J., Stephanie K. Riegg, and Douglas O. Staiger (2006). School Quality, Neighborhoods, and Housing Prices. American Law and Economics Review 8(2), 183-212.

Kane, Thomas J, Douglas Staiger, and Gavin Samms (2003). School Accountability Ratings and Housing Values. Brookings-Wharton Papers on Urban Affairs Black (2), 83-137.

Ma, Lala (2019, jan). Learning in a Hedonic Framework: Valuing Brownfield Remediation. International Economic Review.

Machin, Stephen (2011). Houses and Schools: Valuation of School Quality Through the Housing Market. Labour Economics 18(6), 723 - 729.

Machin, Stephen and Kjell G. Salvanes (2016). Valuing School Quality via a School Choice Reform. Scandinavian Journal of Economics 118(1), 3-24.

Nechyba, Thomas J. (2003). School Finance, Spatial Income Segregation, and the Nature of Communities. Journal of Urban Economics 54(1), 61-88.

Oates, Wallace E. (1969). The Effects of Property Taxes and Local Public Spending on Property Values: An Empirical Study of Tax Capitalization and the Tiebout Hypothesis. Journal of Political Economy 77(6).

Ries, John and Tsur Somerville (2010). School Quality and Residential Property Values: Evidence from Vancouver Rezoning. Review of Economics and Statistics 92(4), 928-944.

Sonstelie, Jon C. and Paul R. Portney (1978). Profit Maximizing Communities and the Theory of Local Public Expenditure. Journal of Urban Economics 5(2), 263-277.

Weimer, David L. and Michael J. Wolkoff (2001). School Performance and Housing Values: Using Non-Contiguous District and Incorporation Boundaries to Identify School Effects. National Tax Journal, 231-253. 


\section{Figures}

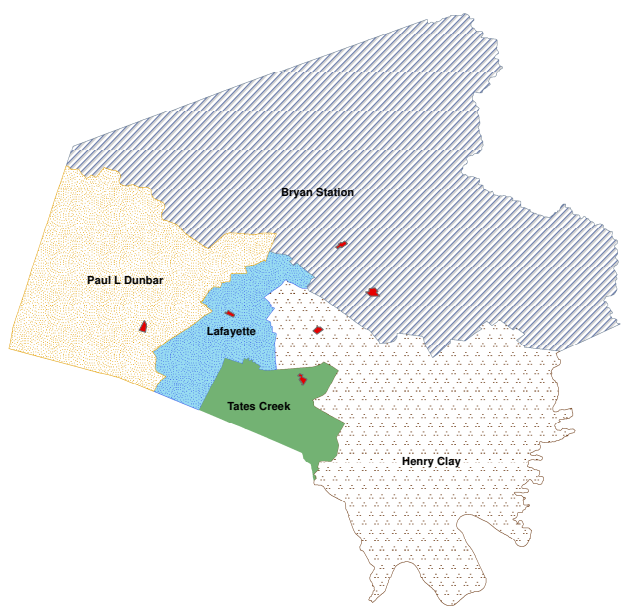

(a) Old School Catchment Boundary

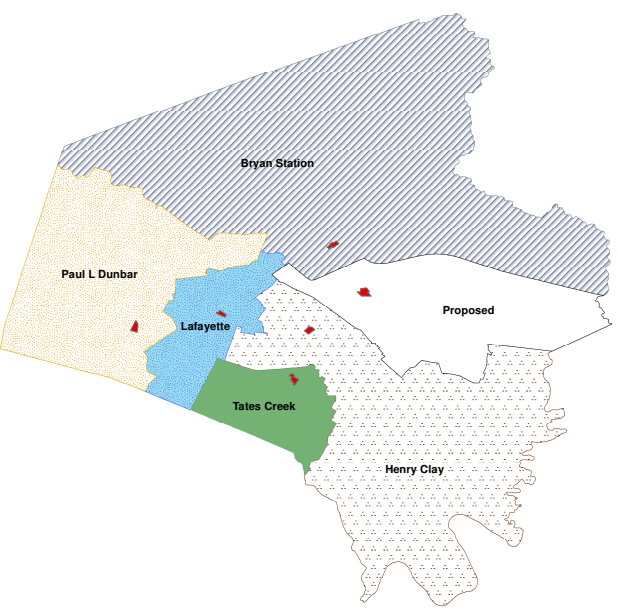

(b) New School Catchment Boundary

Figure 1: Pre- (Old) and Post-Announcement (new) Fayette County High School Catchment Areas 


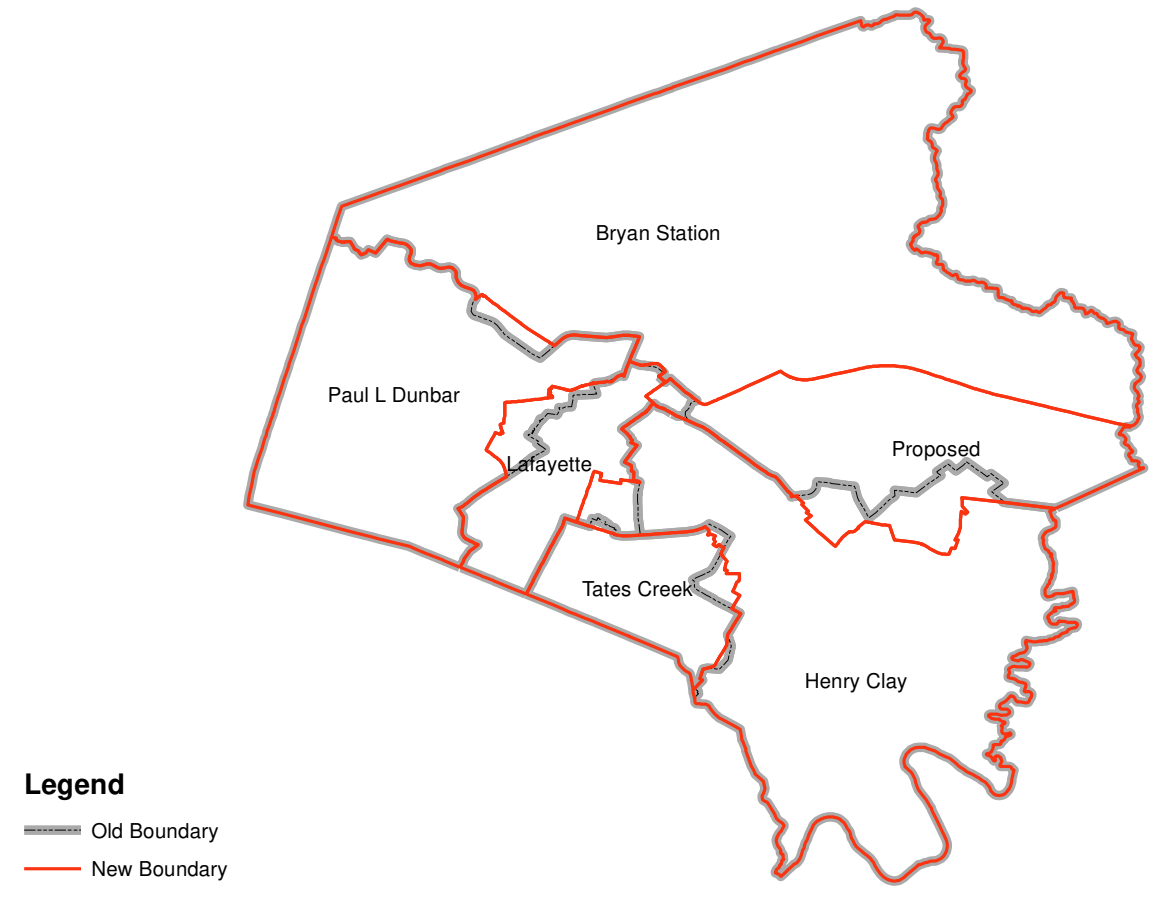

Figure 2: Change in High School Catchment Area Boundaries 


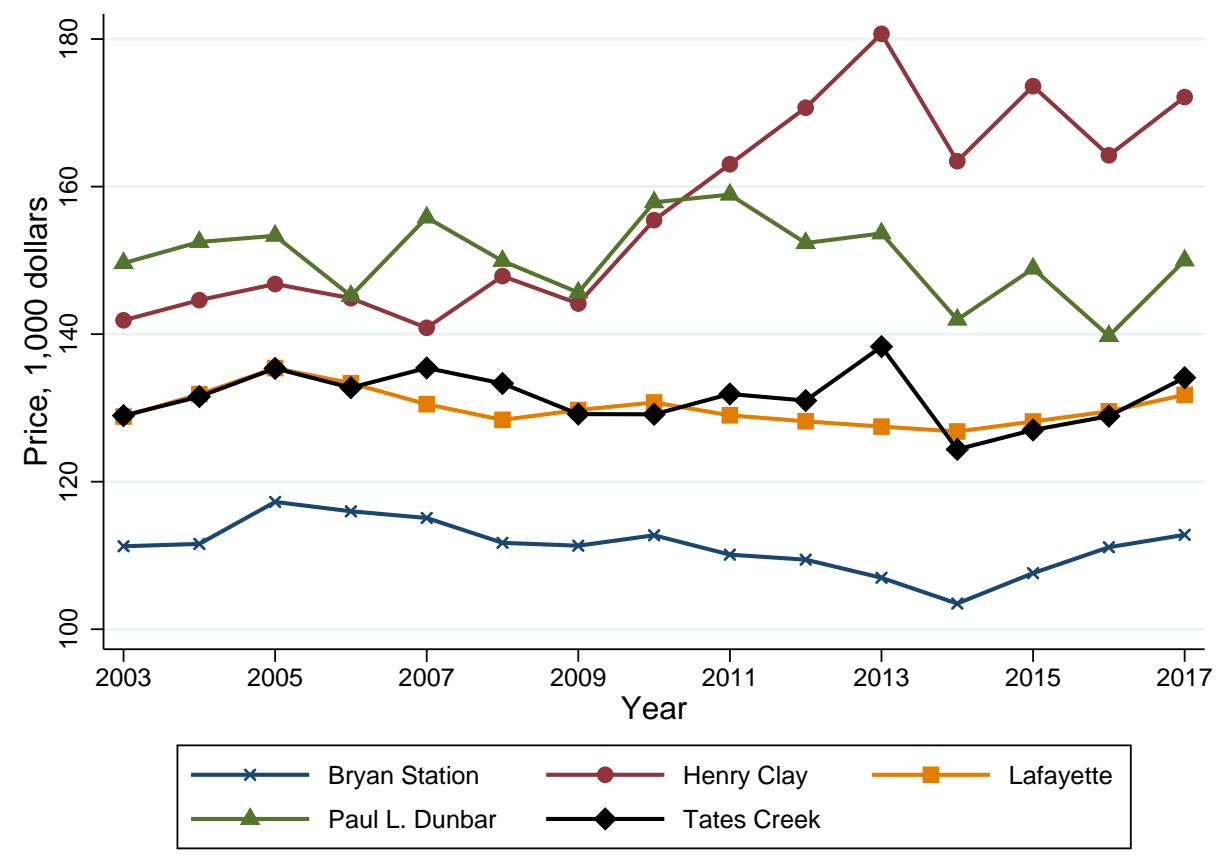

Figure 3: Median House Price by High School Catchment Area and Year Notes: Price data are adjusted by US Urban Housing CPI. 


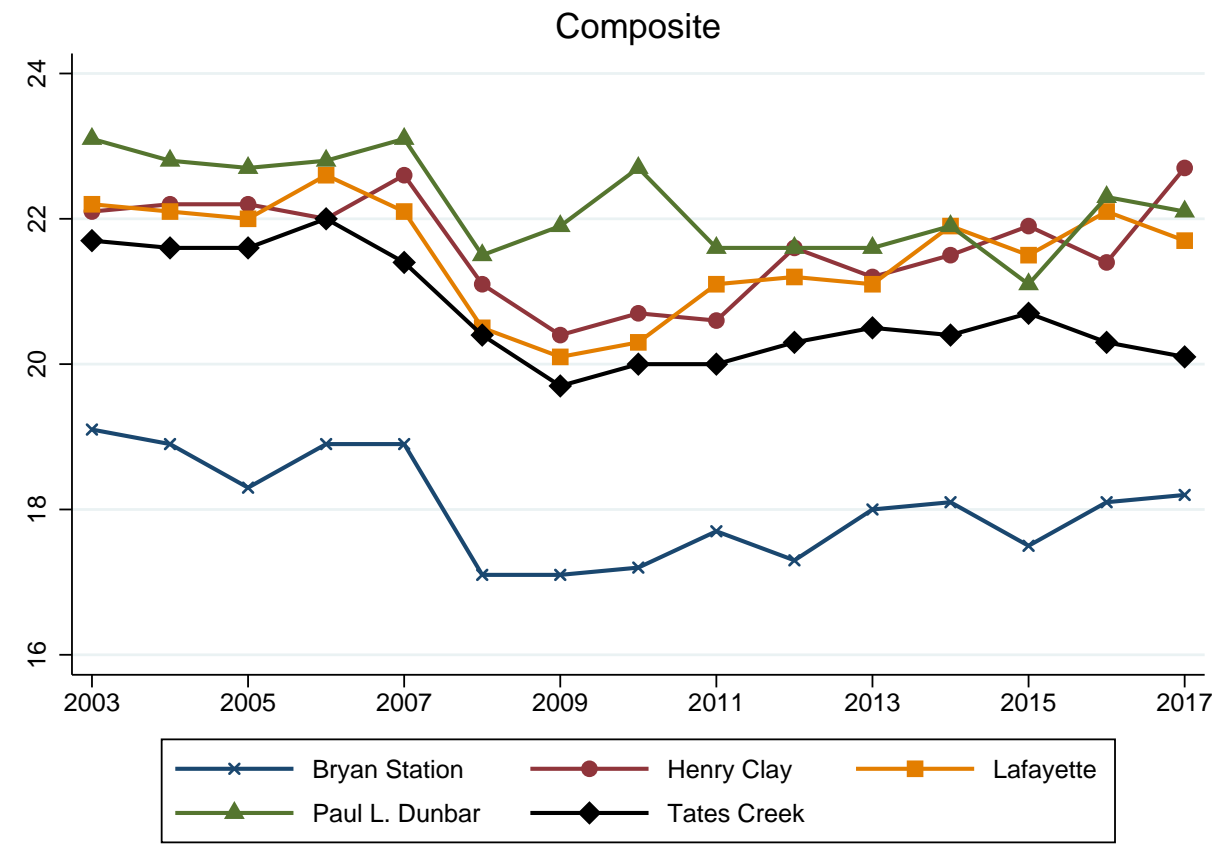

Figure 4: Composite ACT Score by High School and Year 


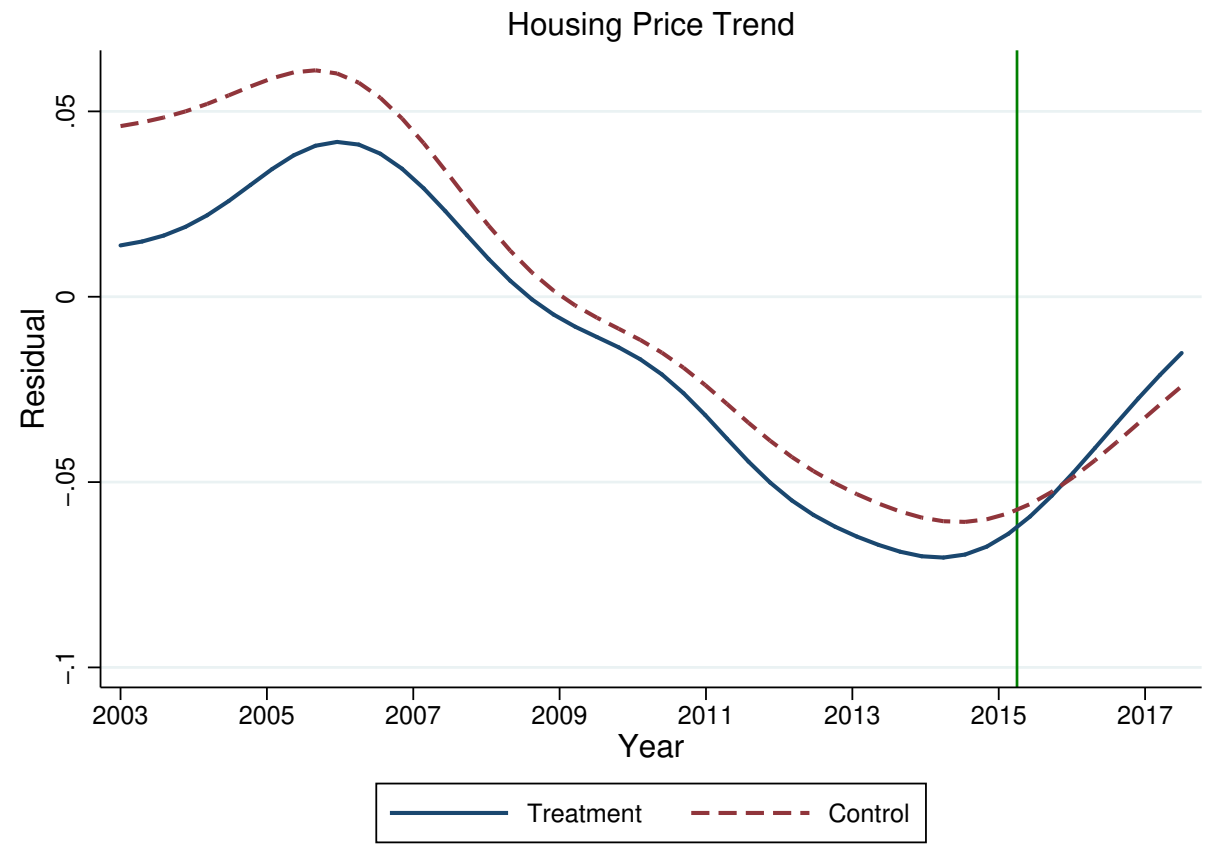

Figure 5: Sales Price Trends for Treatment Group (Houses subject to Redistricting) and Control Group (Houses not subject to Redistricting

Notes: This figure compares the trend of prices in treatment group and control group. We first run a regression with dependent variable being log price, and independent variables including log square footage, house age and age square, number of full bathroom, number of half bathroom, maximum stories, all brick dummy, part brick dummy, urban dummy, distance to urban boundary, distance to city center, distance to park, distance to school, and also school fixed effect. Then we predict the residuals from the regression and collapse residuals at quarterly level. Last we use local polynomial regressions to plot quarterly price residuals against time. 


\section{Tables}

Table 1: Number of Sales based on the Rezoned School Districts, 2003-2017

\begin{tabular}{lccccccc}
\hline & $\begin{array}{c}\text { Bryan } \\
\text { Station }\end{array}$ & $\begin{array}{c}\text { Henry } \\
\text { Clay }\end{array}$ & Lafayette & $\begin{array}{c}\text { Paul L. } \\
\text { Dunbar }\end{array}$ & $\begin{array}{c}\text { Tates } \\
\text { Creek }\end{array}$ & Proposed & Total \\
\hline Bryan Station & 7,153 & 0 & 0 & 1,079 & 0 & 5,591 & 13,823 \\
Henry Clay & 0 & 7,268 & 0 & 0 & 1,290 & 2,342 & 10,920 \\
Lafayette & 0 & 1,088 & 8,918 & 0 & 0 & 204 & 10,210 \\
Paul L. Dunbar & 0 & 0 & 1,403 & 5,611 & 0 & 0 & 7,014 \\
Tates Creek & 0 & 113 & 0 & 0 & 9,130 & 0 & 9,243 \\
\hline Total & 7,153 & 8,469 & 10,321 & 6,690 & 10,420 & 8,137 & 51,190 \\
\hline
\end{tabular}

Notes: This table shows number of sales in each school catchment area in terms of its relative location before and after the redistricting. 
Table 2: Summary Statistics

\begin{tabular}{|c|c|c|c|c|c|c|c|c|}
\hline & $\begin{array}{c}(1) \\
\text { Bryan } \\
\text { Station }\end{array}$ & $\begin{array}{c}(2) \\
\text { Henry } \\
\text { Clay }\end{array}$ & $\begin{array}{c}\text { (3) } \\
\text { Lafayette }\end{array}$ & $\begin{array}{c}(4) \\
\text { Paul L. } \\
\text { Dunbar }\end{array}$ & $\begin{array}{c}(5) \\
\text { Tates } \\
\text { Creek }\end{array}$ & $\begin{array}{c}(6) \\
\text { Treat }\end{array}$ & $\begin{array}{c}\text { (7) } \\
\text { Control }\end{array}$ & $\begin{array}{c}(8) \\
\text { Total }\end{array}$ \\
\hline Sale price & $\begin{array}{l}124,417.5 \\
(57108.1)\end{array}$ & $\begin{array}{c}186,499.5 \\
(105610.1)\end{array}$ & $\begin{array}{l}140,818.6 \\
(55798.1)\end{array}$ & $\begin{array}{c}183,844.9 \\
(101122.4)\end{array}$ & $\begin{array}{l}150,736.5 \\
(68487.0)\end{array}$ & $\begin{array}{l}150,705.0 \\
(76785.5)\end{array}$ & $\begin{array}{l}154,869.5 \\
(83854.5)\end{array}$ & $\begin{array}{l}153,802.9 \\
(82121.4)\end{array}$ \\
\hline Log sale price & $\begin{array}{c}11.65 \\
(0.382)\end{array}$ & $\begin{array}{c}11.99 \\
(0.534)\end{array}$ & $\begin{array}{c}11.79 \\
(0.366)\end{array}$ & $\begin{array}{l}11.98 \\
(0.524)\end{array}$ & $\begin{array}{c}11.84 \\
(0.403)\end{array}$ & $\begin{array}{c}11.82 \\
(0.432)\end{array}$ & $\begin{array}{c}11.83 \\
(0.469)\end{array}$ & $\begin{array}{c}11.83 \\
(0.460)\end{array}$ \\
\hline Log square footage & $\begin{array}{c}7.325 \\
(0.299)\end{array}$ & $\begin{array}{c}7.445 \\
(0.388)\end{array}$ & $\begin{array}{c}7.344 \\
(0.294)\end{array}$ & $\begin{array}{c}7.494 \\
(0.390)\end{array}$ & $\begin{array}{c}7.408 \\
(0.365)\end{array}$ & $\begin{array}{c}7.391 \\
(0.329)\end{array}$ & $\begin{array}{c}7.393 \\
(0.356)\end{array}$ & $\begin{array}{c}7.393 \\
(0.350)\end{array}$ \\
\hline Age at sale date & $\begin{array}{c}22.36 \\
(52.36)\end{array}$ & $\begin{array}{c}35.33 \\
(50.12)\end{array}$ & $\begin{array}{c}41.27 \\
(43.19)\end{array}$ & $\begin{array}{c}30.03 \\
(30.43)\end{array}$ & $\begin{array}{c}24.10 \\
(32.31)\end{array}$ & $\begin{array}{c}24.09 \\
(36.56)\end{array}$ & $\begin{array}{c}32.38 \\
(47.24)\end{array}$ & $\begin{array}{c}30.26 \\
(44.90)\end{array}$ \\
\hline Maximum stories & $\begin{array}{c}1.369 \\
(0.440)\end{array}$ & $\begin{array}{c}1.426 \\
(0.446)\end{array}$ & $\begin{array}{l}1.325 \\
(0.417)\end{array}$ & $\begin{array}{l}1.410 \\
(0.458)\end{array}$ & $\begin{array}{c}1.407 \\
(0.467)\end{array}$ & $\begin{array}{l}1.380 \\
(0.445)\end{array}$ & $\begin{array}{l}1.386 \\
(0.446)\end{array}$ & $\begin{array}{l}1.385 \\
(0.446)\end{array}$ \\
\hline No. of full bathroom & $\begin{array}{c}1.850 \\
(0.568)\end{array}$ & $\begin{array}{c}1.891 \\
(0.728)\end{array}$ & $\begin{array}{c}1.688 \\
(0.587)\end{array}$ & $\begin{array}{c}1.982 \\
(0.827)\end{array}$ & $\begin{array}{c}1.909 \\
(0.626)\end{array}$ & $\begin{array}{c}1.922 \\
(0.659)\end{array}$ & $\begin{array}{c}1.832 \\
(0.665)\end{array}$ & $\begin{array}{c}1.855 \\
(0.665)\end{array}$ \\
\hline No. of half bathroom & $\begin{array}{c}0.427 \\
(0.507)\end{array}$ & $\begin{array}{c}0.485 \\
(0.535)\end{array}$ & $\begin{array}{c}0.397 \\
(0.508)\end{array}$ & $\begin{array}{c}0.565 \\
(0.529)\end{array}$ & $\begin{array}{c}0.554 \\
(0.529)\end{array}$ & $\begin{array}{c}0.476 \\
(0.520)\end{array}$ & $\begin{array}{c}0.475 \\
(0.525)\end{array}$ & $\begin{array}{c}0.475 \\
(0.524)\end{array}$ \\
\hline No. of fireplace & $\begin{array}{c}0.480 \\
(0.513)\end{array}$ & $\begin{array}{c}0.418 \\
(0.508)\end{array}$ & $\begin{array}{c}0.303 \\
(0.462)\end{array}$ & $\begin{array}{c}0.414 \\
(0.530)\end{array}$ & $\begin{array}{c}0.501 \\
(0.510)\end{array}$ & $\begin{array}{c}0.511 \\
(0.519)\end{array}$ & $\begin{array}{c}0.396 \\
(0.502)\end{array}$ & $\begin{array}{c}0.426 \\
(0.509)\end{array}$ \\
\hline All brick & $\begin{array}{c}0.201 \\
(0.400)\end{array}$ & $\begin{array}{c}0.467 \\
(0.499)\end{array}$ & $\begin{array}{c}0.451 \\
(0.498)\end{array}$ & $\begin{array}{c}0.558 \\
(0.497)\end{array}$ & $\begin{array}{c}0.384 \\
(0.486)\end{array}$ & $\begin{array}{c}0.353 \\
(0.478)\end{array}$ & $\begin{array}{c}0.402 \\
(0.490)\end{array}$ & $\begin{array}{c}0.389 \\
(0.488)\end{array}$ \\
\hline Part brick & $\begin{array}{c}0.627 \\
(0.484)\end{array}$ & $\begin{array}{c}0.376 \\
(0.484)\end{array}$ & $\begin{array}{c}0.387 \\
(0.487)\end{array}$ & $\begin{array}{c}0.361 \\
(0.480)\end{array}$ & $\begin{array}{c}0.490 \\
(0.500)\end{array}$ & $\begin{array}{c}0.522 \\
(0.500)\end{array}$ & $\begin{array}{c}0.445 \\
(0.497)\end{array}$ & $\begin{array}{c}0.464 \\
(0.499)\end{array}$ \\
\hline Distance to school & $\begin{array}{c}3.330 \\
(1.776)\end{array}$ & $\begin{array}{c}2.172 \\
(1.177)\end{array}$ & $\begin{array}{c}2.062 \\
(1.237)\end{array}$ & $\begin{array}{c}2.089 \\
(1.447)\end{array}$ & $\begin{array}{c}1.998 \\
(1.317)\end{array}$ & $\begin{array}{c}3.202 \\
(1.264)\end{array}$ & $\begin{array}{c}2.151 \\
(1.530)\end{array}$ & $\begin{array}{c}2.420 \\
(1.537)\end{array}$ \\
\hline Distance to park & $\begin{array}{c}0.541 \\
(0.404)\end{array}$ & $\begin{array}{c}0.476 \\
(0.322)\end{array}$ & $\begin{array}{c}0.475 \\
(0.228)\end{array}$ & $\begin{array}{c}0.427 \\
(0.425)\end{array}$ & $\begin{array}{c}0.451 \\
(0.229)\end{array}$ & $\begin{array}{c}0.497 \\
(0.302)\end{array}$ & $\begin{array}{c}0.477 \\
(0.346)\end{array}$ & $\begin{array}{c}0.482 \\
(0.335)\end{array}$ \\
\hline $\begin{array}{l}\text { Distance to } \\
\text { Urban Service Boul }\end{array}$ & $\begin{array}{c}0.912 \\
(0.725)\end{array}$ & $\begin{array}{c}1.655 \\
(1.202)\end{array}$ & $\begin{array}{c}1.788 \\
(1.076)\end{array}$ & $\begin{array}{c}0.725 \\
(0.638)\end{array}$ & $\begin{array}{c}1.068 \\
(0.634)\end{array}$ & $\begin{array}{l}1.279 \\
(0.874)\end{array}$ & $\begin{array}{l}1.237 \\
(1.024)\end{array}$ & $\begin{array}{c}1.248 \\
(0.988)\end{array}$ \\
\hline Distance to city center & $\begin{array}{c}3.822 \\
(1.370)\end{array}$ & $\begin{array}{c}4.030 \\
(1.861)\end{array}$ & $\begin{array}{c}3.838 \\
(1.628)\end{array}$ & $\begin{array}{c}4.444 \\
(1.603)\end{array}$ & $\begin{array}{c}5.452 \\
(0.807)\end{array}$ & $\begin{array}{c}4.262 \\
(1.435)\end{array}$ & $\begin{array}{c}4.245 \\
(1.670)\end{array}$ & $\begin{array}{c}4.249 \\
(1.613)\end{array}$ \\
\hline Observations & 13,823 & 10,900 & 10,210 & 7,014 & 9,243 & 13,110 & 38,080 & 51,190 \\
\hline
\end{tabular}

Notes: Standard deviations in parentheses. Sale price is adjusted by U.S. urban housing inflation deflator. Distance to school measures the minimum distance to the actual catchment area school. Distance to park, urban service boundary, and city center are referring to the minimum distance to nearest park, urban service boundary and city center. Top and bottom $1 \%$ observations are dropped from data. 
Table 3: Main Results

\begin{tabular}{|c|c|c|c|c|c|c|}
\hline Dependent Variable: LN(Sales Price) & (1) & (2) & (3) & (4) & (5) & $(6)$ \\
\hline \multirow[t]{2}{*}{ Treat } & -0.001 & -0.024 & 0.018 & -0.024 & 0.016 & 0.010 \\
\hline & $(0.030)$ & $(0.027)$ & $(0.057)$ & $(0.027)$ & $(0.052)$ & $(0.050)$ \\
\hline \multirow[t]{2}{*}{ Post } & $-0.077^{* * *}$ & $-0.053^{* * *}$ & $-0.036^{* * *}$ & 0.009 & $0.021^{* * *}$ & $0.018^{* *}$ \\
\hline & $(0.009)$ & (0.009) & $(0.008)$ & $(0.008)$ & $(0.007)$ & $(0.008)$ \\
\hline \multirow[t]{2}{*}{ Treat $\times$ Post } & $0.022^{*}$ & $0.027^{*}$ & 0.004 & $0.029^{* *}$ & 0.004 & $0.024^{*}$ \\
\hline & $(0.013)$ & $(0.014)$ & $(0.011)$ & $(0.013)$ & $(0.010)$ & $(0.012)$ \\
\hline \multirow[t]{2}{*}{ Log of square footage } & $0.947^{* * *}$ & $0.923^{* * *}$ & $0.802^{* * *}$ & $0.929^{* * *}$ & $0.807^{* * *}$ & $0.809^{* * *}$ \\
\hline & $(0.029)$ & $(0.029)$ & $(0.030)$ & $(0.029)$ & $(0.031)$ & $(0.031)$ \\
\hline \multirow[t]{2}{*}{ Age } & -0.074 & $-0.122^{*}$ & $-0.249^{* * *}$ & -0.047 & $-0.143^{* *}$ & $-0.152^{* *}$ \\
\hline & $(0.069)$ & $(0.064)$ & $(0.058)$ & $(0.066)$ & $(0.058)$ & $(0.058)$ \\
\hline \multirow[t]{2}{*}{ Age square } & 0.003 & $0.006^{*}$ & $0.012^{* * *}$ & 0.002 & $0.007^{* *}$ & $0.007^{* *}$ \\
\hline & $(0.003)$ & $(0.003)$ & $(0.003)$ & $(0.003)$ & $(0.003)$ & $(0.003)$ \\
\hline \multirow{2}{*}{ No. full bathrooms } & $0.152^{* * *}$ & $0.147^{* * *}$ & $0.122^{* * *}$ & $0.158^{* * *}$ & $0.132^{* * *}$ & $0.129^{* * *}$ \\
\hline & $(0.012)$ & $(0.012)$ & $(0.009)$ & $(0.012)$ & $(0.010)$ & $(0.009)$ \\
\hline \multirow{2}{*}{ No. half bathrooms } & $0.080^{* * *}$ & $0.079^{* * *}$ & $0.070^{* * *}$ & $0.083^{* * *}$ & $0.074^{* * *}$ & $0.072^{* * *}$ \\
\hline & $(0.008)$ & $(0.009)$ & $(0.006)$ & $(0.009)$ & $(0.006)$ & $(0.006)$ \\
\hline \multirow[t]{2}{*}{ All brick } & $0.124^{* * *}$ & $0.116^{* * *}$ & $0.093^{* * *}$ & $0.116^{* * *}$ & $0.092^{* * *}$ & $0.092^{* * *}$ \\
\hline & $(0.019)$ & $(0.017)$ & $(0.016)$ & $(0.018)$ & $(0.016)$ & $(0.016)$ \\
\hline \multirow{2}{*}{ Part brick } & $0.070^{* * *}$ & $0.072^{* * *}$ & $0.033^{* *}$ & $0.083^{* * *}$ & $0.042^{* *}$ & $0.043^{* *}$ \\
\hline & $(0.018)$ & $(0.019)$ & $(0.017)$ & (0.019) & $(0.016)$ & $(0.017)$ \\
\hline \multirow[t]{2}{*}{ Urban } & 0.047 & 0.057 & $-0.132^{*}$ & 0.091 & -0.108 & -0.112 \\
\hline & $(0.083)$ & $(0.088)$ & $(0.069)$ & $(0.089)$ & $(0.067)$ & $(0.072)$ \\
\hline \multirow[t]{2}{*}{ Stories } & $-0.112^{* * *}$ & $-0.112^{* * *}$ & $-0.103^{* * *}$ & $-0.115^{* * *}$ & $-0.105^{* * *}$ & $-0.105^{* * *}$ \\
\hline & $(0.021)$ & $(0.019)$ & $(0.015)$ & $(0.019)$ & $(0.015)$ & $(0.016)$ \\
\hline \multirow{2}{*}{ Dist to Urban Service Boundary } & $0.095^{* * *}$ & $0.093^{* * *}$ & $0.031^{*}$ & $0.089^{* * *}$ & 0.025 & 0.018 \\
\hline & $(0.019)$ & $(0.020)$ & $(0.018)$ & $(0.020)$ & $(0.019)$ & $(0.019)$ \\
\hline \multirow{2}{*}{ Dist to city center } & $0.025^{* * *}$ & $0.020^{*}$ & -0.005 & $0.023^{* *}$ & -0.003 & -0.016 \\
\hline & $(0.009)$ & $(0.010)$ & $(0.008)$ & $(0.010)$ & $(0.008)$ & $(0.016)$ \\
\hline \multirow[t]{2}{*}{ Dist to nearest park } & 0.018 & 0.031 & 0.006 & 0.039 & 0.013 & 0.022 \\
\hline & $(0.027)$ & $(0.028)$ & $(0.018)$ & $(0.027)$ & $(0.017)$ & $(0.020)$ \\
\hline \multirow{2}{*}{ Dist to school } & $-0.022^{* * *}$ & $-0.017^{* *}$ & -0.005 & $-0.017^{* *}$ & -0.008 & -0.003 \\
\hline & $(0.008)$ & $(0.008)$ & $(0.005)$ & $(0.008)$ & $(0.005)$ & $(0.012)$ \\
\hline School FE & No & Yes & Yes & Yes & Yes & Yes \\
\hline Census Tract FE & No & No & Yes & No & Yes & Yes \\
\hline Year FE & No & No & No & Yes & Yes & Yes \\
\hline Census Tract $\times$ Year FE & No & No & No & No & No & Yes \\
\hline Observations & 51,190 & 51,190 & 51,190 & 51,190 & 51,190 & 51,190 \\
\hline
\end{tabular}

Notes: Each column is a separate regression. Dependent variable is log sale price for all regressions. Age is measured in 100 years. Robust standard errors are clustered at census tract level. ${ }^{*} p<0.10,{ }^{* *} p<0.05,{ }^{* * *} p<0.01$ 
Table 4: Boundary Fixed Effect

\begin{tabular}{|c|c|c|c|c|c|c|}
\hline & $\begin{array}{l}\text { (1) } \\
\text { All }\end{array}$ & $\begin{array}{c}(2) \\
0.4 \mathrm{~m}\end{array}$ & $\begin{array}{c}(3) \\
0.3 \mathrm{~m}\end{array}$ & $\begin{array}{c}(4) \\
0.2 \mathrm{~m}\end{array}$ & $\begin{array}{c}(5) \\
0.1 \mathrm{~m}\end{array}$ & $\begin{array}{c}(6) \\
0.1 \mathrm{~m}\end{array}$ \\
\hline \multicolumn{7}{|c|}{ A. Before (Announced School Redistricting) } \\
\hline ACT Score & $\begin{array}{c}0.001 \\
(0.013)\end{array}$ & $\begin{array}{l}0.033^{* *} \\
(0.014)\end{array}$ & $\begin{array}{c}0.028^{*} \\
(0.015)\end{array}$ & $\begin{array}{l}0.036^{* *} \\
(0.015)\end{array}$ & $\begin{array}{l}0.049^{*} \\
(0.027)\end{array}$ & $\begin{array}{c}0.052^{* * *} \\
(0.019)\end{array}$ \\
\hline Observations & 41,294 & 14,256 & 10,718 & 6,913 & 2,884 & 2,884 \\
\hline \multicolumn{7}{|c|}{ B. After (Announced School Redistricting) } \\
\hline ACT Score & $\begin{array}{c}0.014 \\
(0.017)\end{array}$ & $\begin{array}{c}0.018 \\
(0.016)\end{array}$ & $\begin{array}{c}0.022 \\
(0.017)\end{array}$ & $\begin{array}{c}0.015 \\
(0.025)\end{array}$ & $\begin{array}{c}0.019 \\
(0.014)\end{array}$ & $\begin{array}{c}0.027 \\
(0.020)\end{array}$ \\
\hline Observations & 9,896 & 3,215 & 2,423 & 1,541 & 638 & 638 \\
\hline Boundary FE & No & Yes & Yes & Yes & Yes & No \\
\hline \multicolumn{7}{|c|}{$\begin{array}{l}\text { Notes: Dependent variable is log sale price. Each column is a separate regression. We use } \\
\text { school-year composite test scores to measure the school quality. House characteristics such } \\
\text { as log of square footage, age, number of bathrooms, all brick and partial brick dummies, and } \\
\text { stories are included. We also control for distance to nearest park, distance to urban service } \\
\text { boundary, distance to school, and distance to city center. Census tract by year fixed effects } \\
\text { are also included. Robust standard errors are clustered at census tract level. }{ }^{*} p<0.10 \text {, } \\
p<0.05,{ }^{* * *} p<0.01\end{array}$} \\
\hline
\end{tabular}


Table 5: Log of Sale Price on ACT Scores, Pre- and Post-Catchment Area Changes

\begin{tabular}{lcccc}
\hline Dependent Variable: LN(Sales Price) & $(1)$ & $(2)$ & $(3)$ & $(4)$ \\
\hline ACT Score & $0.025^{* * *}$ & 0.001 & -0.002 & 0.000 \\
& $(0.010)$ & $(0.012)$ & $(0.011)$ & $(0.010)$ \\
Post (Announced Redistricting) & & & -0.053 & -0.087 \\
& & $(0.056)$ & $(0.056)$ \\
Score $\times$ Post & & 0.004 & $0.005^{*}$ \\
& & & $(0.003)$ & $(0.003)$ \\
Treat (Change in School Catchment Area) & & & 0.010 \\
Treat $\times$ Post & & & & $0.050)$ \\
& No & Yes & Yes & Yes \\
\hline School FE & 51,190 & 51,190 & 51,190 & 51,190 \\
\hline Observations & & & & \\
\hline
\end{tabular}

Notes: Dependent variable is log of house price. Each column is a separate regression. House characteristics such as log of square footage, age, number of bathrooms, all brick and partial brick dummies, and stories are included. We also control for distance to nearest park, distance to urban service boundary, distance to school, and distance to city center. Census tract by year fixed effects are also included. ${ }^{*} p<0.10,{ }^{* *} p<0.05,{ }^{* * *} p<0.01$ 


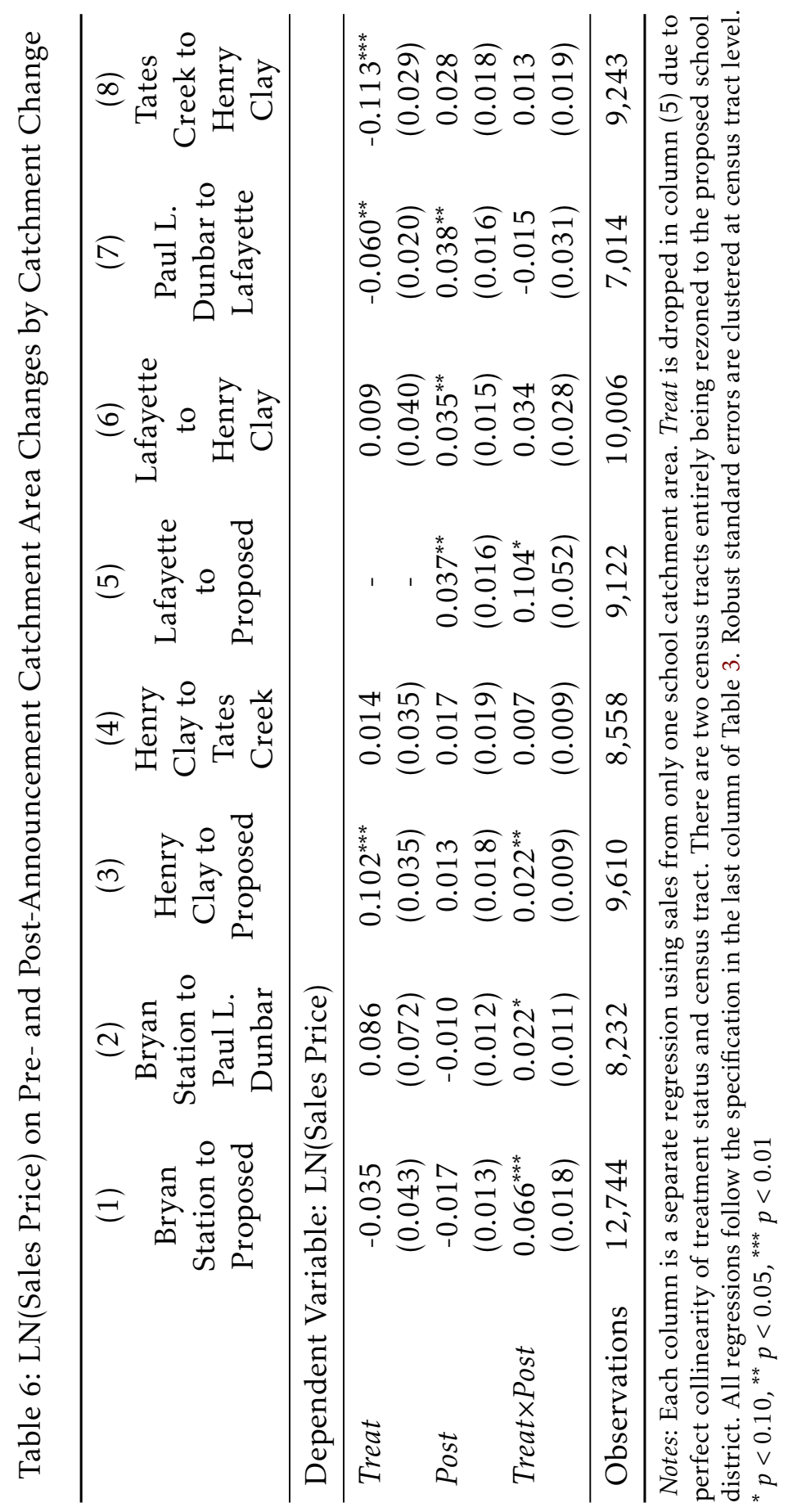


Table 7: Housing Stock Value Change

\begin{tabular}{ccc}
\hline School Catchment Area & Value Change $(\$)$ & Number of Houses \\
\hline Bryan Station & $85,776,669$ & 7,912 \\
Henry Clay & $15,206,688$ & 2,783 \\
Lafayette & $7,237,464$ & 1,308 \\
\hline Total & $108,220,821$ & 12,003 \\
\hline
\end{tabular}

Notes: This table provides estimates of houses that will be rezoned to the new school catchment area based on 2013 fair cash value. Total value of housing stock in these three school catchment areas that will be rezoned to the new school catchment area is $\$ 2,060,450,600$ in 2013 . 


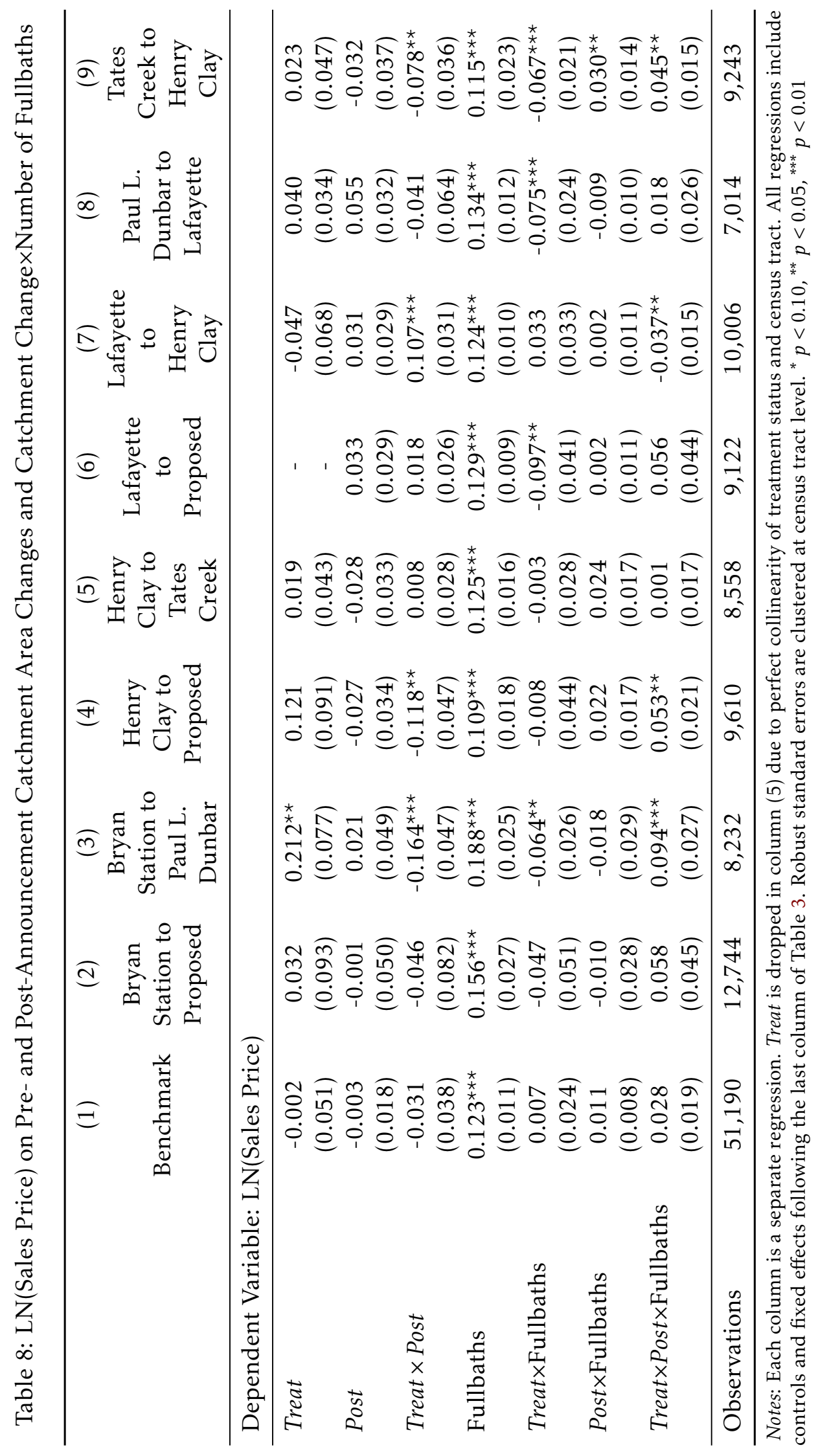




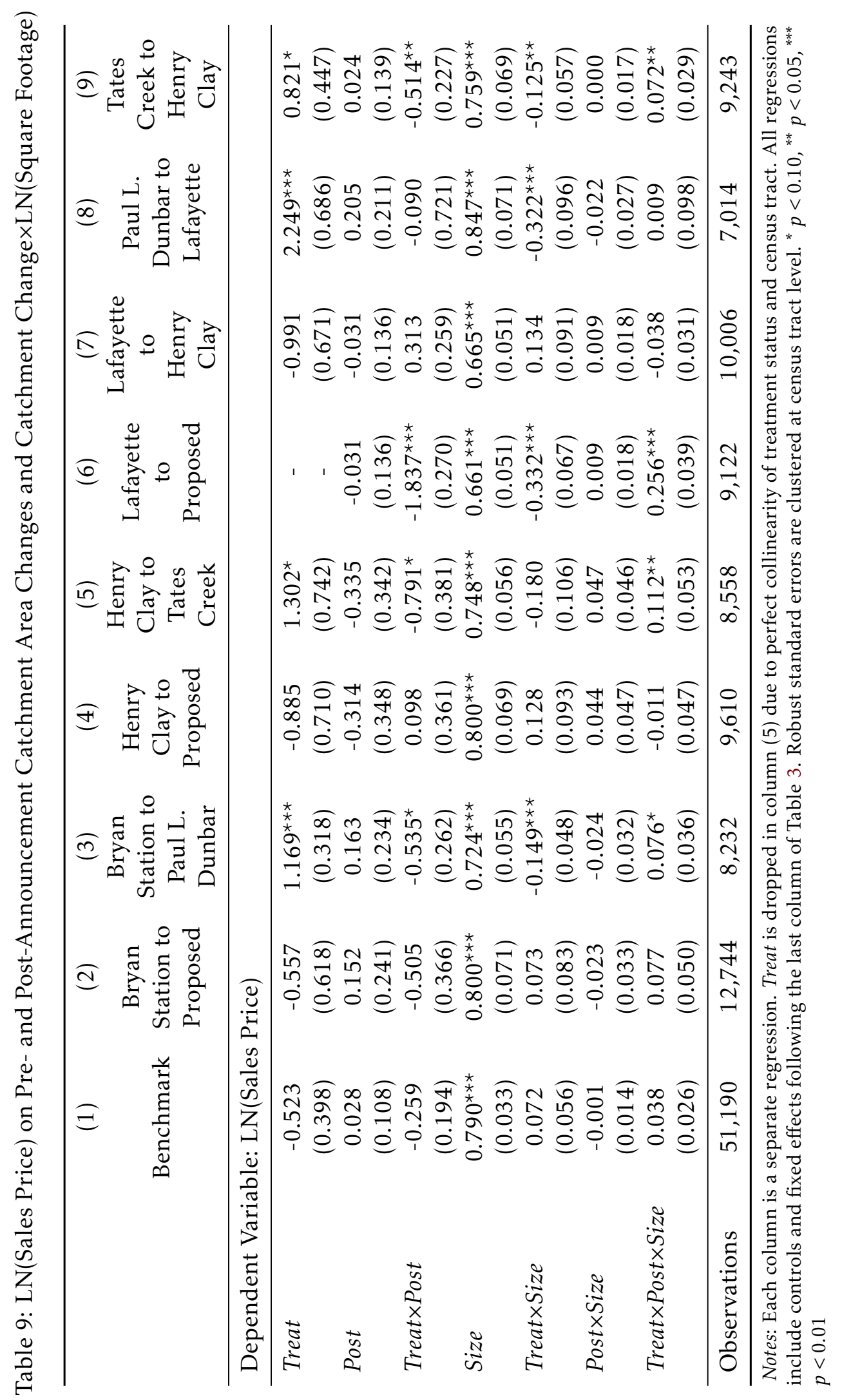




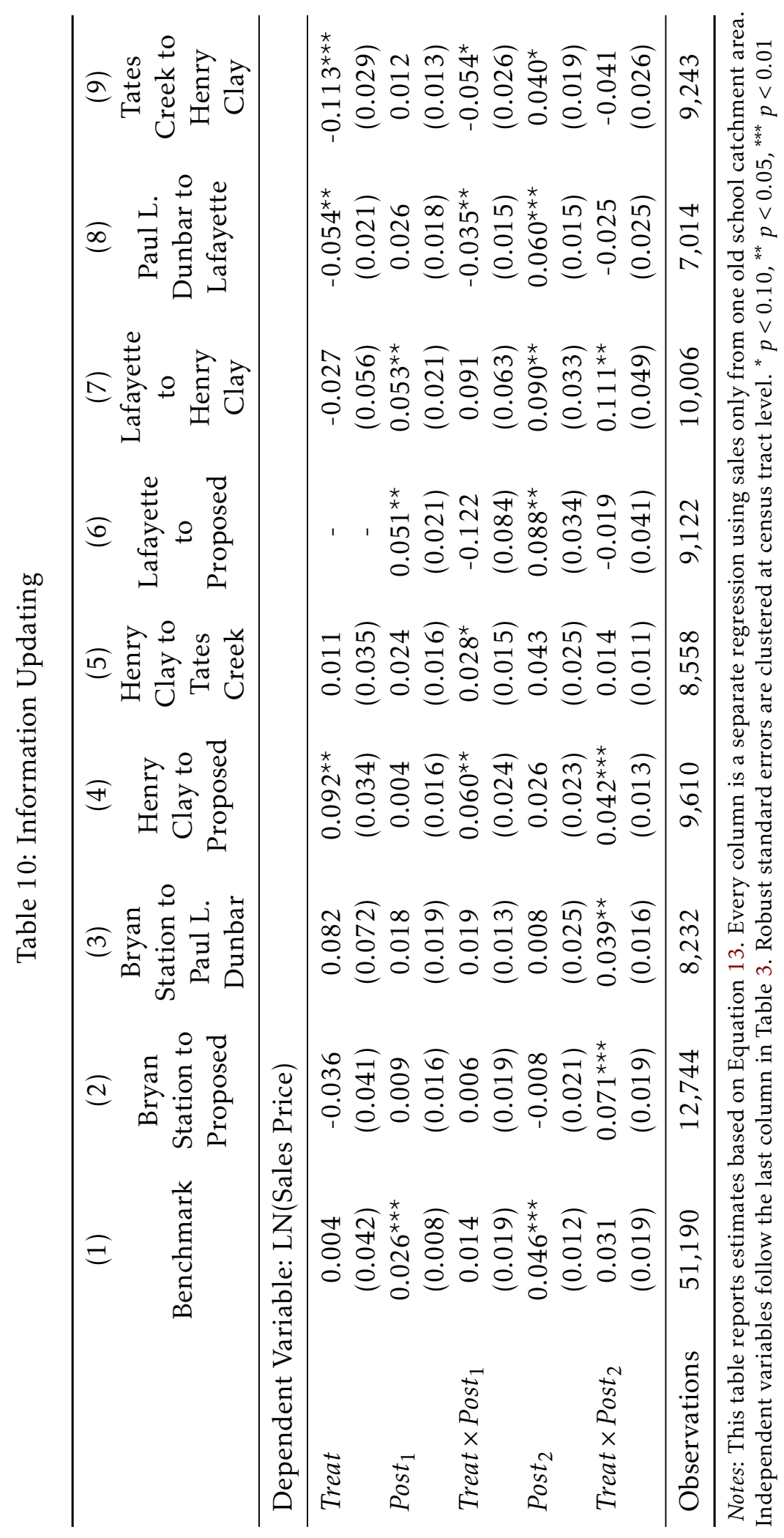


Table 11: Placebo Test

\begin{tabular}{lccccc}
\hline & $(1)$ & $(2)$ & $(3)$ & $(4)$ & $(5)$ \\
& Bryan Station & Henry Clay & Lafayette & Paul L. Dunbar & Tates Creek \\
\hline Treat & 0.001 & -0.003 & -0.009 & 0.003 & -0.001 \\
Post & $(0.006)$ & $(0.008)$ & $(0.009)$ & $(0.004)$ & $(0.011)$ \\
& -0.013 & 0.020 & $0.036^{* *}$ & 0.027 & 0.028 \\
Treat $\times$ Post & $(0.013)$ & $(0.021)$ & $(0.015)$ & $(0.016)$ & $(0.019)$ \\
& 0.008 & 0.012 & 0.005 & 0.020 & -0.033 \\
& $(0.008)$ & $(0.022)$ & $(0.019)$ & $(0.011)$ & $(0.041)$ \\
\hline Observations & 7,153 & 7,268 & 8,918 & 5,611 & 9,130 \\
\hline
\end{tabular}

Notes: We randomly assign treatment status to non-treated group in each old school district. We do not distinguish the rezoned school district in placebo test and generally compare the fake treatment effect for each old school district. All regressions follow the specification in the last column of Table 3. Robust standard errors are clustered at census tract level. ${ }^{*} p<0.10,{ }^{* *} p<0.05,{ }^{* * *} p<0.01$ 